\title{
CANCRO BACTERIANO DO TOMATEIRO: METODOLOGIA DE INOCULAÇÃO, REAÇÃO DE GENÓTIPOS DO HOSPEDEIRO E EFICIÊNCIA DE QUÍMICOS SOBRE O CONTROLE
}

\author{
ADRIANA ZANIN KRONKA
}

Tese apresentada à Escola Superior de Agricultura "Luiz de Queiroz", Universidade de São Paulo, para obtenção do título de Doutor em Agronomia, Área de Concentração: Fitopatologia.

P I R A C I C A B A

Estado de São Paulo - Brasil

Janeiro - 2004 


\title{
CANCRO BACTERIANO DO TOMATEIRO: METODOLOGIA DE INOCULAÇÃO, REAÇÃO DE GENÓTIPOS DO HOSPEDEIRO E EFICIÊNCIA DE QUÍMICOS SOBRE O CONTROLE
}

\section{ADRIANA ZANIN KRONKA}

Engenheiro Agrônomo

Orientador: Prof. Dr. IVAN PAULO BEDENDO

\begin{abstract}
Tese apresentada à Escola Superior de Agricultura "Luiz de Queiroz", Universidade de São Paulo, para obtenção do título de Doutor em Agronomia, Área de Concentração: Fitopatologia.
\end{abstract}

P I R A C I C A B A

Estado de São Paulo - Brasil

Janeiro - 2004 


\section{Dados Internacionais de Catalogação na Publicação (CIP) DIVISÃO DE BIBLIOTECA E DOCUMENTAÇÃO - ESALQ/USP}

\section{Kronka, Adriana Zanin}

Cancro bacteriano no tomateiro : metodologia de inoculação, reação de genótipos do hospedeiro e eficiência de químicos sobre o controle / Adriana Zanin Kronka. - Piracicaba, 2004.

$79 \mathrm{p}$.

Tese (doutorado) - Escola Superior de Agricultura Luiz de Queiroz, 2004. Bibliografia.

1. Cancro bacteriano do tomateiro 2. Controle químico 3. Genótipo vegetal 4. Resistência genética vegetal I. Título 
"Chegar ao objetivo é importante se assimilamos as lições aprendidas no percurso.

A conquista, além disso, transforma-se em um ponto de partida para iniciar outra busca

e continuar aprendendo"

(Paulo Coelho)

Aos meus familiares,

Sérgio, Silvia, Graziela, Gustavo, Branca, Giselda, Amaury, Maurício, Mirela, Tayne e Stella

AGRADEÇO pelo apoio em todos os momentos, pela confiança na minha capacidade, pela paciência, amor e carinho, e, especialmente, pelo incentivo na busca dos meus ideais. A vocês DEDICO esse "vitória" que conquistamos juntos 


\section{AGRADECIMENTOS}

A autora expressa seus agradecimentos a todos que, direta ou indiretamente, colaboraram para a realização deste trabalho, em especial às seguintes pessoas e instituições:

Ao Prof. Dr. Ivan Paulo Bedendo, pela oportunidade oferecida, confiança, orientação, amizade e colaboração a minha formação profissional;

Aos professores Dr. Sérgio F. Pascholatti, Dr. Nelson S. Massola Junior, Dr. Jorge A. M. Resende e Dr. José O. M. Menten, pelas sugestões apresentadas;

Ao Prof. Dr. Sérgio do Nascimento Kronka, pela orientação no planejamento experimental e nas análises estatísticas;

À Coordenação de Aperfeiçoamento de Pessoal de Nível Superior (CAPES), pela concessão da Bolsa de Doutorado;

Aos professores Dr. Chukichi Kurozawa e Dra. Leila Trevisan Braz, pela atenção dispensada;

Às Empresas Sakata Seed Sudamerica Ltda., Horticeres Sementes Ltda., Hortec Sementes Ltda., SVS do Brasil Sementes Ltda. e Clause Tezier do Brasil Ltda., pelo fornecimento das sementes; 
À Syngenta Proteção de Cultivos Ltda., pela disponibilização dos produtos químicos;

À Dra. Rita de Cássia Panizzi, sempre disposta a ouvir e ajudar, pela amizade, colaboração e palavras de incentivo;

Ao Dr. Ricardo Gioria pela valiosa contribuição durante a condução dos ensaios e interpretação dos resultados, pela imensa paciência e amizade;

A Ana Paula, Luiz Fernando e Marília pela inestimável colaboração na instalação dos experimentos, pela amizade e pelos bons momentos compartilhados;

Aos professores do Setor de Fitopatologia da ESALQ, pelos ensinamentos;

Aos funcionários do Setor de Fitopatologia da ESALQ, pela colaboração e amizade;

Às bibliotecárias e funcionárias da Seção de Pós-Graduação, pela atenção dispensada;

A Carol, Marta e Bringel, pela amizade, e aos demais colegas de curso, pela convivência;

À Dra. Maria Heloisa D. Moraes e à Dra. Margarete Camargo, pela amizade e incentivo;

Aos amigos Lito, Fabiana, Elaine, André e João Pedro, que, mesmo distantes, estavam sempre presentes;

Aos amigos Míriam, Maria, Gafa, Fer, Vanda e Verinha, pela amizade e pelos importantíssimos momentos de descontração. 


\section{SUMÁRIO}

Página

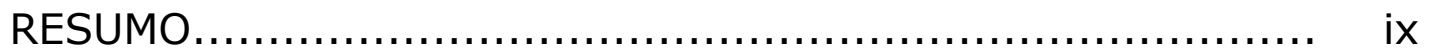

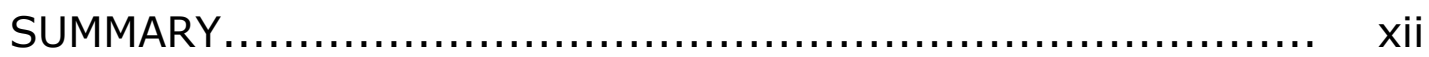

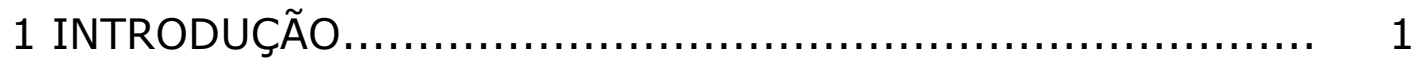

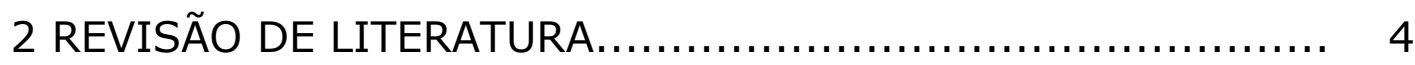

2.1 Cancro bacteriano do tomateiro........................... 4

2.2 Sintomatologia da doença.................................... 5

2.3 Etiologia e epidemiologia.................................... 7

2.4 Controle do cancro bacteriano do tomateiro................... 10

2.4.1 Medidas gerais de controle do cancro bacteriano........... 10

2.4.2 Medidas complementares para o controle do cancro bacteriano..................................................... 11

2.4.2.1 Resistência genética ao cancro bacteriano do tomateiro....................................................... 11

2.4.2.2 Controle químico do cancro bacteriano do tomateiro....................................................... 14

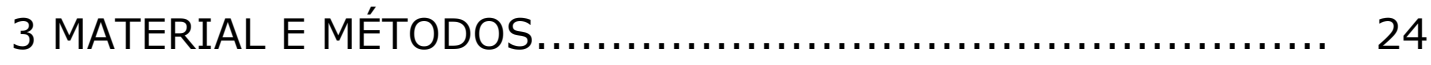

3.1 Origem, cultivo e preservação do isolado bacteriano......... 24

3.2 Instalação dos ensaios........................................ $\quad 25$ 
3.2.1 Obtenção das plantas hospedeiras........................ 25

3.2.2 Obtenção do inóculo bacteriano............................. 26

3.2 .3 Avaliação dos ensaios..................................... 26

3.3 ETAPA I: Metodologia de inoculação de Clavibacter michiganensis subsp. michiganensis em tomateiro............... 27

3.3.1 Ensaio I: Comparação entre diversos métodos de inoculação associados a diferentes concentrações de inóculo bacteriano

3.3.2 Ensaio II: Efeito da idade da planta de tomate sobre o desenvolvimento do cancro bacteriano.

3.4 ETAPA II: Reação de genótipos de tomateiro à inoculação com Clavibacter michiganensis subsp. michiganensis.

3.5. ETAPA III: Controle do cancro bacteriano do tomateiro através do emprego de produtos químicos

3.5.1 Efeito do acibenzolar-S-metil e outros produtos fitossanitários no controle do cancro bacteriano do tomateiro em condições de telado.

3.5.2 Efeito in vitro do acibenzolar-S-metil e outros produtos fitossanitários sobre Clavibacter michiganensis subsp. michiganensis

4 RESULTADOS E DISCUSSÃO.

4.1 ETAPA I: Metodologia de inoculação de Clavibacter michiganensis subsp. michiganensis em tomateiro.................

4.1.1 Ensaio I: Comparação entre diversos métodos de inoculação associados a diferentes concentrações de inóculo bacteriano.... 
4.1.2 Ensaio II: Efeito da idade da planta de tomate sobre o desenvolvimento do cancro bacteriano.......................... 42

4.2 ETAPA II: Reação de genótipos de tomateiro à inoculação com Clavibacter michiganensis subsp. michiganensis.

4.3 ETAPA III: Controle do cancro bacteriano do tomateiro através do emprego de produtos químicos...................... 46 4.3.1 Efeito do acibenzolar-S-metil e outros produtos fitossanitários no controle do cancro bacteriano do tomateiro em condições de telado

4.3.2 Efeito in vitro do acibenzolar-S-metil e outros produtos fitossanitários sobre Clavibacter michiganensis subsp. michiganensis.

5 DISCUSSÃO....................................................

5.1 ETAPA I: Metodologia de inoculação de Clavibacter michiganensis subsp. michiganensis em tomateiro.

5.2 ETAPA II: Reação de genótipos de tomateiro à inoculação com Clavibacter michiganensis subsp. michiganensis.

5.3 ETAPA III: Controle do cancro bacteriano do tomateiro através do emprego de produtos químicos....................... 56

6 CONCLUSÕES 


\title{
CANCRO BACTERIANO DO TOMATEIRO: METODOLOGIA DE INOCULAÇÃO, REAÇÃO DE GENÓTIPOS DO HOSPEDEIRO E EFICIÊNCIA DE QUÍMICOS SOBRE O CONTROLE
}

\author{
Autor: ADRIANA ZANIN KRONKA \\ Orientador: Prof. Dr. IVAN PAULO BEDENDO
}

\section{RESUMO}

O cancro bacteriano, causado por Clavibacter michiganensis subsp. michiganensis $(\mathrm{Cmm})$, é uma das doenças mais importantes da cultura do tomate (Lycopersicon esculentum Mill.), especialmente para tomateiros estaqueados. O controle está fundamentado na adoção de um conjunto de medidas preventivas, pois poucas são as informações sobre materiais resistentes à doença e não existe um produto químico que a controle eficientemente. Os objetivos desta tese foram determinar um método de inoculação adequado à seleção de genótipos de tomateiro resistentes ao cancro bacteriano; avaliar a reação de genótipos de tomateiro à inoculação com $\mathrm{Cmm}$; e avaliar o efeito de acibenzolar-S-metil e outros produtos fitossanitários no controle da doença. Para o ensaio de metodologia, foram avaliados 
quatro métodos de inoculação (aspersão de suspensão bacteriana na face inferior das folhas; aspersão, sob pressão, de suspensão bacteriana na face inferior das folhas; corte do sistema radicular, com tesoura, seguido de imersão na suspensão bacteriana; e ferimento na haste com alfinete entomológico transpassando uma gota de suspensão de inóculo depositada na axila foliar) e três concentrações de inóculo $\left(10^{8} \mathrm{ufc} / \mathrm{mL}, 10^{7} \mathrm{ufc} / \mathrm{mL}\right.$ e $\left.10^{6} \mathrm{ufc} / \mathrm{mL}\right)$. Posteriormente, foi avaliado o efeito da inoculação em plantas com diferentes idades, aos 7, 14, 21 e 28 dias após a emergência. Foram utilizados os genótipos Kadá e Rotam-4 e um isolado bacteriano proveniente de Bragança Paulista, SP. A avaliação foi realizada através de uma escala descritiva, atribuindo-se notas que foram convertidas em índice de murcha bacteriana. A inoculação de $\mathrm{Cmm}$, quatorze dias após a emergência das plantas, através da aspersão de suspensão bacteriana $\left(10^{8} \mathrm{ufc} / \mathrm{mL}\right)$ na face inferior das folhas, com avaliação aos 30 dias após inoculação, foi a metodologia mais apropriada para a avaliar a reação de genótipos de tomateiro. Estabelecida a metodologia, foram avaliados dez genótipos comerciais de tomateiro (Carmen, Débora max, IPA-6, Santa Clara, Alambra, Júpiter, Olimpo, Fanny, Jumbo e Densus) para identificação de materiais resistentes ao cancro bacteriano, tendo-se Kadá e Rotam-4 como controles suscetível e resistente, respectivamente. Alambra e Jumbo apresentaram comportamento semelhante a Rotam-4, sendo materiais promissores para o plantio em áreas com histórico de ocorrência da doença. Para a avaliação de controle do cancro bacteriano foram testados os seguintes produtos: acibenzolar-S-metil (ASM), ASM + mancozeb, ASM + oxicloreto de cobre, mancozeb + oxicloreto de cobre, e oxitetraciclina. Três esquemas de aplicação dos produtos foram 
adotados: $\left(E_{1}\right) 4$ aplicações (a primeira e a segunda realizadas seis e três dias antes da inoculação; a terceira e a quarta, aos três e seis dias após a inoculação); ( $\left.E_{2}\right)$ apenas as duas aplicações préinoculação; $\left(E_{3}\right)$ apenas as duas aplicações pós-inoculação. Esses produtos foram incorporados a meio de cultura para avaliação in vitro de seus efeitos sobre $\mathrm{Cmm}$. Independente da forma de aplicação, o ASM, isolado ou em mistura com fungicidas, proporcionou reduções significativas na severidade da doença e não inibiu o desenvolvimento da bactéria in vitro. 


\title{
BACTERIAL CANKER OF TOMATO: INOCULATION METHODOLOGY, REACTION OF HOST GENOTYPES AND EFFICIENCY OF CHEMICALS ON THE CONTROL
}

\author{
Author: ADRIANA ZANIN KRONKA \\ Adviser: Prof. Dr. IVAN PAULO BEDENDO
}

\section{SUMMARY}

Bacterial canker, caused by Clavibacter michiganensis subsp. michiganensis $(\mathrm{Cmm})$, is one of the most important diseases of tomato (Lycopersicon esculentum Mill.). Its control is based on a set of preventive measures, once there is a few information about resistant materials and the chemical control is not efficient. The objectives of this thesis were to determine a suitable inoculation methodology to bacterial canker resistance studies; to evaluate the reaction of commercial tomato genotypes to the inoculation with $\mathrm{Cmm}$; and to evaluate the acibenzolar-S-methyl and other phytossanitary products effects on the control of that disease. To methodology trial, four inoculation methods were evaluated, including foliar pulverization with bacterial suspension; foliar pulverization 
under pressure with bacterial suspension; cutting of roots with scissor, followed by their immersion in bacterial suspension; and stem wounding with a pin passing over a drop of inoculum suspension deposited on the insertion point of leaf. Besides the inoculation methods, three inoculum concentrations were investigated: $10^{8}$ $\mathrm{cfu} / \mathrm{mL} ; 10^{7} \mathrm{cfu} / \mathrm{mL}$ and $10^{6} \mathrm{cfu} / \mathrm{mL}$. Later, it was evaluated the effect of inoculation on plants with different ages: 7, 14, 21 and 28 days after emergency. To those trials, genotypes Kadá and Rotam-4, and a bacterial isolate from Bragança Paulista, SP, were employed. The evaluation was accomplished through a descriptive scale, being attributed notes that were turned into bacterial wilt index. Inoculation of $\mathrm{Cmm}$, fourteen days after emergency of plants, through aspersion with bacterial suspension $\left(10^{8} \mathrm{cfu} / \mathrm{mL}\right)$ over the inferior face of leaves, and evaluation 30 days after inoculation, was the most appropriated methodology to evaluate resistance to bacterial canker in tomato genotypes. After the establishment of the inoculation methodology, ten commercial tomato genotypes (Carmen, Débora max, IPA-6, Santa Clara, Alambra, Jupiter, Olimpo, Fanny, Jumbo and Densus) were investigated to identify resistant materials to the bacterial canker. Kadá and Rotam-4 were employed as susceptible and resistant controls, respectively. Alambra and Jumbo had a similar behavior to Rotam-4, being the most promising materials for the planting in areas with report of occurrence of bacterial canker. To evaluate the bacterial canker control following products were tested: acibenzolar-S-methyl (ASM), ASM + mancozeb, ASM + copper oxicloride, mancozeb + copper oxicloride, and oxytetracycline. Three schemes of application of the products were adopted: $\left(E_{1}\right) 4$ applications (first and second ones were accomplished six and three 
days before inoculation; third and fourth ones, three and six days after inoculation); $\left(E_{2}\right)$ two applications before inoculation only; $\left(E_{3}\right)$ two applications after inoculation only. The effect in vitro of these products on $\mathrm{Cmm}$ was also evaluated. ASM, isolated or in mixture with fungicides, provided significant reductions in the disease severity independent of the scheme of application and had no effect on bacterial development in vitro. 


\section{INTRODUÇÃO}

O tomateiro tem sua origem no continente sul-americano, em uma região montanhosa dos Andes, no Peru, Equador e Chile. Sua domesticação e cultivo parecem ter ocorrido primeiramente nas antigas civilizações do México. Apesar de ter o seu valor alimentício reconhecido desde o século XVI, somente três séculos depois, o tomate cultivado (Lycopersicon esculentum Mill.) passou a ter amplo emprego na dieta humana.

Atualmente, o tomateiro é a segunda hortaliça em importância econômica, sendo superada apenas pela cultura da batata. No Brasil, a produção de tomate atingiu mais de três milhões de toneladas em 2001. A cultura é explorada em quase todos os estados brasileiros, destacando-se Goiás, São Paulo e Minas Gerais.

A cultura está sujeita a várias doenças que podem limitar sua produção, dependendo do nível de resistência genética da cultivar. Dentre essas doenças, está o cancro bacteriano do tomateiro, causado por Clavibacter michiganensis subsp. michiganensis. Embora seja uma doença aparentemente sem importância para o tomate industrial, o cancro bacteriano é bastante freqüente em tomateiros estaqueados, provocando perdas consideráveis, principalmente nas regiões Sul, Sudeste e CentroOeste do Brasil. 
O sucesso do controle do cancro bacteriano do tomateiro está fundamentado na adoção de um conjunto de medidas de caráter preventivo, uma vez que não existe um produto químico que controle eficientemente a doença, depois que esta se instalou na lavoura.

A utilização de cultivares que apresentem algum nível de resistência corresponde a uma medida complementar de controle da doença.

Para o cancro bacteriano, o tomateiro apresenta resistência do tipo quantitativa ou horizontal, estando, portanto, mais sujeito às influências do ambiente. Por este motivo, a metodologia de inoculação e os parâmetros de avaliação da doença devem ser criteriosamente determinados quando se deseja identificar material com algum nível de resistência, seja para plantio ou para melhoramento genético visando variedades mais resistentes.

A baixa eficiência dos antibióticos e de fungicidas cúpricos, usualmente empregados na tentativa de controlar a doença, e a possibilidade do surgimento de populações bacterianas resistentes a estes produtos têm levado à procura de novas alternativas para o controle. Nesse contexto, a resistência sistêmica adquirida (RSA) tem merecido especial atenção como medida auxiliar no manejo de doenças de plantas. O acibenzolar-S-metil tem sido demonstrado como um potente ativador de RSA, proporcionando a proteção, em condições de campo, em diversos patossistemas.

Diante da importância que o cancro bacteriano representa para a cultura do tomateiro e da adoção de medidas que proporcionem um controle eficiente da doença, o presente trabalho foi desenvolvido tendo-se os seguintes objetivos: 
a) determinar um método de inoculação adequado à avaliação da reação de genótipos de tomateiro à bactéria Clavibacter michiganensis subsp. michiganensis;

b) avaliar a reação de genótipos comerciais de tomateiro à inoculação com Clavibacter michiganensis subsp. michiganensis; e

c) avaliar o efeito de acibenzolar-S-metil e outros produtos fitossanitários no controle do cancro bacteriano. 


\section{REVISÃO DE LITERATURA}

O tomateiro (Lycopersicon esculentum Mill.), pertencente à família Solanaceae, é originário do continente Sul Americano, da região andina compreendida pelo Equador, Chile e Peru, sendo encontrado numa altitude de até 2000 metros. Foi domesticado primeiramente no México, há vários séculos (Minami \& Haag, 1989). Atualmente, está entre as hortaliças mais consumidas mundialmente, tanto in natura como industrializada, devido à versatilidade de uso, valor nutritivo, menor perecibilidade comparativamente às outras hortaliças e possibilidade de processamento industrial (Tighelaar, 1991). Esta hortaliça ocupa a segunda posição mundial, em termos de importância econômica, estando atrás apenas da cultura da batata. Em 2002, o Brasil produziu aproximadamente 3.608 milhões de toneladas, apresentando uma produtividade média de 58,55 t/ha. O Estado de São Paulo, responsável por $21,23 \%$ da produção nacional de tomates, produziu 765.990 toneladas em 11930 hectares (FNP Consultoria \& Comércio, 2003).

\subsection{Cancro bacteriano do tomateiro}

A cultura do tomateiro está sujeita a várias doenças que, dependendo do nível de resistência genética da cultivar usada, podem limitar sua produção. 
O cancro bacteriano do tomateiro é uma doença séria, com ampla distribuição geográfica. Causada pela bactéria Clavibacter michiganensis subsp. michiganensis $(\mathrm{Cmm})$, esta doença foi primeiramente observada em casa de vegetação, em Michigan, nos Estados Unidos da América, em 1909 (Gitaitis, 1991).

No Brasil, os primeiros relatos do cancro bacteriano do tomateiro datam de 1956 (Galli \& Tokeshi, 1979; Maffia et al., 1980), tendo sido a doença primeiramente observada no Estado de São Paulo. Dois anos mais tarde, assumiu grande importância para a cultura, causando perdas de $40 \%$ a $50 \%$ na produção (Maffia et al., 1980).

A doença, aparentemente inexpressiva para o tomate indústria, é altamente destrutiva para o tomate estaqueado. A alta incidência do cancro bacteriano em tomateiros estaqueados pode ser atribuída à utilização de sementes contaminadas ou infectadas, ao plantio de cultivares suscetíveis e à baixa eficiência de controle químico, aliados às operações de transplante, amarração e desbrota que favorecem a disseminação, inoculação e penetração da bactéria na planta (Kurozawa, 1984).

\subsection{Sintomatologia da doença}

O tomateiro apresenta-se suscetível ao cancro bacteriano em qualquer estádio de desenvolvimento da cultura e a penetração da bactéria pode ocorrer através de quaisquer órgãos da planta. A bactéria produz dois tipos de colonização em tomateiro: a localizada e a sistêmica, ambas resultando em sintomas bem distintos que, 
entretanto, podem variar com diversos fatores (Galli \& Tokeshi, 1979; Kurozawa, 1984, Gleason et al., 1993; Kurozawa \& Pavan, 1997).

A colonização localizada prevalece nas culturas de verão, quando as chuvas são mais abundantes e favorecem a disseminação da bactéria de uma planta para a outra. Os sintomas iniciais nos folíolos variam desde encharcamento, seguido de necrose, até pequenas elevações de forma circular, com centro esbranquiçado, que se rompem, liberando a bactéria e formando pequenos cancros de 1 a $2 \mathrm{~mm}$ de diâmetro de centro suberoso. Outro sintoma é a queima dos bordos dos folíolos, em conseqüência da penetração do patógeno pelos hidatódios. As lesões nas hastes, ráquis e pecíolos são semelhantes às do limbo foliar. Na superfície dos frutos, os sintomas apresentam-se como lesões circulares, brancas, com 1 a $3 \mathrm{~mm}$ de diâmetro, que se rompem, formando um tecido suberificado no centro e um halo esbranquiçado. Estas lesões são chamadas de "olho de passarinho" ou "olho de perdiz" e, quando ocorrem em grande número, provocam a deformação dos frutos (Galli \& Tokeshi, 1979; Gitaitis, 1991; Gleason et al., 1993; Kurozawa \& Pavan, 1997).

A colonização sistêmica pode ocorrer desde a germinação da semente até a planta adulta e, de modo geral, os sintomas se manifestam, em condições de campo, após um mês do transplante ou mais tarde (Galli \& Tokeshi, 1979). A colonização sistêmica resulta em murcha parcial ou total das plantas afetadas. A bactéria pode penetrar por aberturas naturais (estômatos e hidatódios) e ferimentos, inclusive pelas raízes. Além de murcha, pode ocorrer necrose dos bordos dos folíolos da metade da folha, apenas da metade da planta ou de toda a planta. O sintoma interno da colonização sistêmica envolve a alteração da coloração da região vascular, de amarela a 
pardo-escura. A manifestação de sintomas de murcha das folhas intensifica-se a partir do início da frutificação, quando os frutos não se desenvolvem normalmente e caem com facilidade (Galli \& Tokeshi, 1979; Kurozawa \& Pavan, 1997). Com o deslocamento do patógeno do xilema para as proximidades do floema $e$ das células parenquimáticas, desenvolvem-se estrias de coloração amarela a marrom ao longo dos caules afetados e na face inferior dos pecíolos. Estas estrias escurecem gradualmente e, algumas vezes, racham, resultando em cancros marrom escuros que revelam necrose da medula e do córtex (Gleason et al., 1993).

\subsection{Etiologia e epidemiologia}

A bactéria causadora do cancro bacteriano do tomateiro foi primeiramente denominada de Bacterium michiganense e, depois, de Aplanobacter michiganense, por Erwin F. Smith (citado por Gleason et al., 1993). Após várias tentativas de renomear a bactéria, o que incluiu as denominações Pseudomonas michiganensis, Phytomonas michiganensis, Erwinia michiganensis e Mycobacterium michiganense, adotou-se a nomenclatura Corynebacterium michiganense (Dowson citado por Romeiro, 1995), a qual permaneceu por aproximadamente cinqüenta anos. Na década de 1980, a bactéria foi reclassificada no gênero Clavibacter, tendo-se por base o conteúdo de ácido 2,4diaminobutílico de sua parede celular, e passou a ser denominada de Clavibacter michiganensis subsp. michiganensis (Davis et al. citados por Gleason et al., 1993).

Clavibacter michiganensis subsp. michiganensis é uma bactéria gram positiva, baciliforme, móvel ou imóvel (Kurozawa \& 
Pavan, 1997), havendo controvérsias quanto à presença ou ausência de flagelos. Enquanto alguns pesquisadores admitem a motilidade da bactéria (Shoemaker \& Echandi, 1976; Jarvis, 1981), outros não constataram sua motilidade (Bryan, 1930; Wakimoto et al., 1968; Strider, 1969). Quando desenvolvidas em meio nutriente-ágar, as culturas de $\mathrm{Cmm}$ são amareladas, com a região central mais escura, quando examinadas contra a luz (Kurozawa \& Pavan, 1997).

A bactéria sobrevive em restos de cultura (Farley, 1971; Jarvis, 1981; Gleason et al., 1993), solos (Strider, 1967; Wakimoto et al., 1968; Strider, 1969; Jarvis, 1981), sementes (Bryan, 1930; Chang et al., 1992b) e hospedeiras alternativas (Strider, 1969; Volcani et al., 1970; Thyr, 1971a; Thyr et al., 1975; Galli \& Tokeshi, 1979; Kurozawa \& Pavan, 1997). Segundo Goto (1992), Cmm é capaz de sobreviver por sete a oito meses, em condições de ar seco, na superfície de estacas de madeira, caixas e arames, e por até quinze meses em tecidos de tomateiros. Miguel-Wruck et al. (2001) observaram que $\mathrm{Cmm}$ sobreviveu associada a estacas de bambu por até 100 dias, no interior de casa de vegetação e em ambiente externo.

As principais formas de disseminação são água de irrigação, a curta distância, e sementes contaminadas com a bactéria, a longa distância (Kimura et al., 1977; Lopes \& Santos, 1994).

Segundo Nedumaran \& Vidhyasekaran (1982), cerca de $8 \%$ dos casos de infecção são decorrentes de sementes contaminadas, as quais apresentam significativa perda de germinação e vigor. Estes autores observaram que, quando sementes infectadas por $\mathrm{Cmm}$ eram semeadas em solos esterilizados, as plantas apresentavam a bacteriose após um mês. 
Resultados experimentais de campo mostraram que uma taxa de transmissão de $\mathrm{Cmm}$ de sementes para plântulas de 0,01\% poderia iniciar uma séria epidemia de cancro bacteriano em campos de produção de sementes (Chang et al., 1991; Gitaitis et al., 1991). Segundo Gitaitis et al. (1991), num campo, uma semente infestada em 10000 sementes pode resultar em $100 \pm 25$ focos de infecção por hectare e, nessas condições, a poda do topo acarreta em centenas de plantas com infecção sistêmica latente.

As práticas agrícolas de pulverização de produtos químicos, poda, amarração e colheita, além da água de irrigação, possibilitam a disseminação da bactéria em campos de produção. Esses mecanismos de disseminação sugerem que $\mathrm{Cmm}$, como muitas outras bactérias fitopatogênicas, permanece como população epífita sobre a superfície das folhas (Gleason et al., 1991; Chang et al., 1992b; Gleason et al., 1993).

As condições favoráveis ao desenvolvimento da bactéria são temperaturas entre 24 e $28^{\circ} \mathrm{C}$ e alta umidade (Galli \& Tokeshi, 1979; Tokeshi \& Carvalho, 1980; Kurozawa \& Pavan, 1997). A temperatura ótima para o desenvolvimento da infecção sistêmica é de $28^{\circ} \mathrm{C}$, estando o ótimo de umidade do solo entre $40 \%$ e $80 \%$ da capacidade de campo. A doença incide com maior intensidade em plantas bem adubadas e evolui com maior rapidez em plantas jovens (Galli \& Tokeshi, 1979; Tokeshi \& Carvalho, 1980). Segundo Chang et al. (1992a), o período de incubação é longo e o desenvolvimento dos sintomas é menos severo quando a temperatura é baixa, as plantas estão velhas, as concentrações de inóculo são baixas e as cultivares apresentam resistência moderada. 


\subsection{Controle do cancro bacteriano do tomateiro}

\subsubsection{Medidas gerais de controle do cancro bacteriano}

etiologia bacteriana requerem atenção especial, pois seus agentes causais representam importantes patógenos de plantas, tanto pelos prejuízos que acarretam, como pela facilidade com que se disseminam e pela dificuldade de serem eficientemente controladas.

Conforme relatado anteriormente, a bactéria $C$. michiganensis subsp. michiganensis apresenta alta disseminação em condições de campo e, por este motivo, seu controle envolve uma série de medidas preventivas, visando impedir a sua introdução e conseqüente disseminação na plantação. Assim, as medidas gerais de controle do cancro bacteriano do tomateiro incluem: utilização de sementes e mudas sadias (Strider \& Konsler, 1965; Strider, 1969; Tokeshi \& Carvalho, 1980; Jarvis, 1981; Kurozawa, 1984; Gitaitis, 1991; Lopes \& Santos, 1994; Kurozawa \& Pavan, 1997); tratamento químico ou térmico de sementes (Tokeshi \& Carvalho, 1980; Kurozawa, 1984; Gitaitis, 1991; Lopes \& Santos, 1994; Kurozawa \& Pavan, 1997); utilização de estacas novas ou desinfestadas com água sanitária ou outro desinfestante (Gitaitis, 1991; Lopes \& Santos, 1994; Kurozawa \& Pavan, 1997); tratamento de mourões, arames, bandejas de semeadura, madeiramento e implementos (Strider, 1969; Tokeshi \& Carvalho, 1980; Jarvis, 1981; Kurozawa, 1984; 
Gitaitis, 1991; Kurozawa \& Pavan, 1997); rotação de culturas, preferencialmente com gramíneas (Kurozawa, 1984; Gitaitis, 1991; Gleason et al., 1993; Lopes \& Santos, 1994; Kurozawa \& Pavan, 1997); aração profunda, após a colheita, para enterrio e decomposição acelerada de restos culturais (Gleason et al., 1993); controle de plantas daninhas e plantas de tomate voluntárias (Gleason et al., 1993); cuidados com a qualidade da água de irrigação, evitando-se, sempre que possível, a irrigação por aspersão (Kurozawa, 1984; Lopes \& Santos, 1994; Kurozawa \& Pavan, 1997).

\subsubsection{Medidas complementares para o controle do cancro bacteriano}

A utilização de cultivares que apresentem algum nível de resistência e o emprego de produtos químicos são apontados como medidas auxiliares de controle do cancro bacteriano do tomateiro (Kurozawa \& Pavan, 1997).

\subsubsection{Resistência genética ao cancro bacteriano do tomateiro}

O progresso no desenvolvimento de resistência genética ao cancro bacteriano tem sido modesto. Acredita-se que variedades com suficiente grau de resistência e adequadas características agronômicas, desenvolvidas através dos avanços nos programas de melhoramento tradicional e do emprego da biotecnologia, possam estar disponíveis comercialmente num futuro próximo (Gleason et al., 1993). 
A grande variação nas respostas de genótipos em função da agressividade do patógeno e dos procedimentos de inoculação dificulta comparações e a obtenção de resultados consistentes referentes à resistência ao cancro bacteriano, o que retarda o lançamento de qualquer variedade comercial (Strider, 1969; Thyr, 1972; De Jong \& Honma, 1976; Berry et al., 1989; Gleason et al., 1993).

Segundo Kurozawa (1984), para se iniciar um trabalho de pesquisa, visando a determinação de fontes de resistência ou a seleção de plantas resistentes num programa de melhoramento, é fundamental se conhecer o tipo de resistência envolvida, que, no caso do cancro bacteriano do tomateiro, é a resistência horizontal ou quantitativa. Segundo o autor, em função deste tipo de resistência, as plantas estão mais sujeitas às influências do ambiente, do método de inoculação e do potencial de inóculo. Este fato ressalta a importância dos procedimentos adotados para a inoculação das plantas e dos parâmetros de avaliação para a condução de programas de melhoramento.

Diversos métodos de inoculação têm sido adotados nos estudos do cancro bacteriano do tomateiro. Dentre esses estão: inserção de fio de escova dental, previamente mergulhado no inóculo, na haste das plantas (Forster \& Echandi, 1973); corte do pecíolo com tesoura contaminada em inóculo (Thyr, 1968; De Jong \& Honma, 1976; Chang et al., 1992a); corte dos cotilédones com tesoura previamente imersa no inóculo (Kimura et al., 1978; Kurozawa \& Leite Junior, 1981a,b); inserção de palito dental, previamente imerso no inóculo, na haste da planta (Kimura et al., 1978; Kurozawa \& Leite Junior, 1981a,b); imersão do sistema radicular em suspensão 
bacteriana (Hassan et al., 1968); aspersão de suspensão bacteriana em folhas (Kurozawa \& Leite Junior, 1981a,b) e flores (Medina-Mora et al., 2001).

Além do método de inoculação, a concentração de inóculo tem importante papel no estudo da resistência de materiais, devendo ser ajustada ao método empregado.

Segundo Forster \& Echandi (1973), a inserção de fio de escova dental previamente imerso em suspensão bacteriana, a $10^{7}$ ufc/mL, no caule de plantas com cinco semanas de idade, é um método recomendável para estudo de resistência.

De Jong \& Honma (1976) verificaram melhor diferenciação entre plantas resistentes e suscetíveis empregando-se o método do corte de pecíolo com tesoura contaminada com inóculo a $4 \times 10^{8}$ $\mathrm{ufc} / \mathrm{mL}$, quando comparado à inoculação de raízes ou folhas.

Kimura et al. (1978), sugeriram os seguintes métodos de inoculação e respectivas concentrações de inóculo, para a seleção de plantas resistentes: corte dos cotilédones e $3 \times 10^{8} \mathrm{ufc} / \mathrm{mL}$; inserção de palito dental no caule pouco acima dos cotilédones e $3 \times 10^{6}$ $\mathrm{ufc} / \mathrm{mL}$; micropipetas e $3 \times 10^{7} \mathrm{ufc} / \mathrm{mL}$; e nas folhas cotiledonares a 3 $x 10^{8} \mathrm{ufc} / \mathrm{mL}$, recomendando avaliações aos vinte dias para o processo nas hastes e aos sete dias para o processo em folhas cotiledonares.

Apesar das várias técnicas de inoculação de plantas de tomate com C. michiganensis subsp. michiganensis apresentadas na literatura, não há método padrão relatado para seleção visando a identificação de materiais de tomate resistentes ao cancro bacteriano. Ressalta-se, portanto, a importância de se buscar um método de 
inoculação econômico, fácil, eficiente e com resultados reproduzíveis, tanto no campo como em condições de casa de vegetação.

\subsubsection{Controle químico do cancro bacteriano do tomateiro}

O controle químico de doenças bacterianas, baseado principalmente no emprego de fungicidas cúpricos e antibióticos, em geral, mostra-se ineficiente.

Os fungicidas cúpricos, amplamente utilizados num passado recente, vêm sendo substituídos pelos fungicidas sistêmicos. Por serem aplicados de forma preventiva, os fungicidas cúpricos estão mais sujeitos às intempéries climáticas, tendo sua eficácia consideravelmente reduzida. Além disso, o aparecimento de populações de bactérias resistentes a tais produtos tem contribuído para diminuir sua utilização (Lopes, 2000).

Os antibióticos requerem maior freqüência de aplicações, por não serem tão persistentes e eficientes quanto os fungicidas. A fitotoxidade destes produtos representa outro fator limitante ao seu emprego. Além disso, a possibilidade da utilização de antibióticos dentro de uma estratégia de manejo integrado é também limitada pelo surgimento de populações bacterianas resistentes aos mesmos, em função de seu uso indevido e indiscriminado (Lopes, 2000).

Com a diminuição da utilização de fungicidas cúpricos e as limitações do emprego de antibióticos, as doenças bacterianas tornaram-se mais freqüentes, ocasionando maiores perdas, o que tem levado os produtores a buscar medidas alternativas que, empregadas dentro de uma filosofia de manejo integrado, propiciem um controle mais efetivo das doenças. Nessa busca por novas táticas de controle 
de doenças, verifica-se uma grande preocupação em assegurar a produção, tanto em qualidade, quanto em quantidade, sem agredir o meio ambiente (Silva, L., 2002; Soares \& Maringoni, 2002; Silva et al., 2003a,b). Neste sentido, a exploração de mecanismos latentes de resistência das próprias plantas mostra-se como uma alternativa viável no manejo de doenças (Silva et al., 2003a,b).

A resistência sistêmica adquirida (RSA) tornou-se objeto de pesquisa crescente em todo o mundo, visto que se trata de um fenômeno envolvendo a ativação de barreiras químicas e físicas contra patógenos (Misaghi, 1982; Kessmann et al., 1994b; Inbar et al., 1998).

As primeiras descrições de resistência induzida datam de 1901, quando esse fenômeno foi estudado por Ray e Beauverie, no patossistema Botrytis cinerea-Begonia sp. (Kessmann et al., 1994b; Romero et al., 2001).

Em 1961, Ross (citado por Ryals et al., 1994) detalhou a ocorrência de RSA em plantas de fumo (Nicotiana tabacum L.), que apresentavam lesões locais quando infectadas com vírus do mosaico do fumo (TMV). Segundo este autor, as lesões locais que ocorriam em fumo após a inoculação do TMV eram restringidas por uma inoculação prévia com o mesmo patógeno, restrição esta que também ocorria efetivamente contra patógenos fúngicos e bacterianos, além de outros vírus. Ross (citado por Romero et al., 2001) empregou o termo "systemic acquired resistance" (resistência sistêmica adquirida) para explicar esse tipo de resistência de amplo espectro e longa duração.

Segundo Silva, L. (2002), os trabalhos de Ross despertaram a atenção para o assunto e impulsionaram as pesquisas que objetivam compreender tal fenômeno. Outro fator que contribuiu 
para aumentar a importância da RSA como ferramenta no manejo integrado de doenças foi a descoberta de indutores químicos da resistência sistêmica contra patógenos (Silva et al., 2003a,b).

Entre as substâncias abióticas capazes de induzir resistência, destacam-se o ácido salicílico (AS) e seus análogos, como o acibenzolar-S-metil [sulfo-metil-éster do ácido benzo $(1,2,3)$ thiadiazole-7-cabotióico] e o ácido 2,6 dicloroisonicotínico (INA). Até o momento, o AS e o INA não apresentam potencial para uso comercial, pois são fitotóxicos para a maioria da plantas cultivadas (Kessmann et al., 1994a,b; Romero et al., 2001; Silva, L., 2002; Silva et al., 2003a,b). O acibenzolar-S-metil (ASM) é um ativador exógeno que atua como um análogo funcional do AS (Agrawal et al., 1999). Após sua aplicação, o mesmo é rapidamente absorvido e translocado por toda a planta, desencadeando um sinal sistêmico e ativando a expressão de genes de defesa, proporcionando, dessa maneira, alterações semelhantes àquelas resultantes da atuação do AS (Silva et al., 2003a,b).

Pertencente à classe química denominada de benzothiadiazole, o ASM é o primeiro de uma nova geração de produtos utilizados na proteção de plantas, denominados de ativadores de plantas ou indutores de resistência (Knight et al., 1997; Cole, 1999; Abbasi et al., 2002). Este produto interfere nos processos fisiológico e bioquímico das plantas, induzindo resistência sistêmica a agentes fitopatogênicos (Knight et al., 1997), mesmo em plantas incapazes de acumular AS (Delaney, 1997).

O ASM atende aos critérios exigidos para um agente ser considerado um indutor de RSA: ele dá proteção ao mesmo espectro de patógenos que aquele verificado no caso da RSA ativada 
biologicamente; causa a expressão dos mesmos marcadores moleculares e bioquímicos (isto é, proteínas relacionadas à patogênese) que indutores biológicos; e não apresenta atividade antimicrobiana direta (Kessmann et al., 1994a,b; Sticher et al., 1997; Romero et al., 2001; Ruess, citado por Silva, L., 2002).

Devido ao fato de apresentar modo de ação inespecífico e não apresentar toxicidade inerente, o risco de seleção de isolados resistentes ao ASM dentro de uma população de patógenos é muito pequeno (Pascholatti et al., 1999; Silva et al., 2003a,b).

Até o momento, o ASM é o único indutor de RSA liberado para uso comercial em alguns países (Knight et al. 1997; Silva, L., 2002), tendo sido liberado para comercialização na Europa e Estados Unidos com os nomes comerciais Bion e Actigard, respectivamente. No Brasil, também comercializado com o nome de Bion, o produto está registrado para as culturas de tomate, cacau e citros, mas existem relatos de indução de resistência por ASM em outras culturas.

A eficiência do ASM como indutor de resistência a doenças já foi relatada em diversas espécies de plantas, contra patógenos de etiologia fúngica, bacteriana e viral.

Friedrich et al. (1996) observaram que plantas de fumo pré-inoculadas com Tobacco mosaic virus (TMV) ou tratadas com ASM mostraram-se resistentes aos fungos Cercospora nicotianae e Phytophthora parasitica, às bactérias Erwinia carotovora e Pseudomonas syringae pv. tabaci, e ao vírus TMV. Para a mesma cultura, Cole (1999) verificou que o ASM limitou efetivamente a incidência de $P$. syringae pv. tabaci e dos fungos $C$. nicotianae e Thanatephorus cucumis. Segundo a autora, a resistência induzida pelo ASM reduziu a incidência das doenças causadas por tais patógenos, 
tanto em sementeiras, como no campo. Csinos et al. (2001) não constataram redução na infecção de plantas de fumo por $P$. parasitica var. nicotianae pela aplicação do ASM, mas verificaram que a utilização deste reduziu significativamente a infecção pelo vírus Tomato spotted wilt virus (TSWV).

Jensen et al. (1998) avaliaram o efeito do ASM no tratamento de sementes de duas espécies de brássicas e verificaram significativa redução na intensidade de esporulação de Peronospora parasitica e na ocorrência de tombamento causado por Rhizoctonia solani.

Jesus Júnior et al. (1999) estudaram a ação indutora de resistência do ASM pulverizado em feijoeiro contra o fungo Phaeoisariopsis griseola, agente causal da mancha angular, e a bactéria Xanthomonas axonopodis pv. phaseoli, agente causal do crestamento bacteriano comum, mostrando redução na severidade de aproximadamente $50 \%$ para a mancha angular e $37,2 \%$ para o crestamento bacteriano. Por outro lado, Siegrist et al. (citados por Soares \& Maringoni, 2002) verificaram que não houve indução de resistência pelo emprego de ASM para o crestamento do halo do feijoeiro, causado por Pseudomonas savastanoi pv. phaseolicola. Soares \& Maringoni (2002) observaram que o ASM foi fitotóxico ao feijoeiro, quando aplicado via tratamento de sementes, ocasionando uma redução drástica do número de plantas com desenvolvimento normal, tanto no teste de germinação, quanto no teste de vigor. Os autores constataram, ainda, que o produto não apresentou eficiência na indução de resistência à murcha-de-Curtobacterium, quando aplicado em tratamento de sementes ou em pulverização das plantas. 
Segundo Brisset et al. (2000), o ASM protegeu plântulas, mudas e árvores de maçã contra a infecção de Erwinia amylovora, quando aplicado previamente à inoculação. A proteção proporcionada pela aplicação do ASM foi similar àquela observada com a aplicação de antibiótico (estreptomicina).

Resende et al. (2002) observaram eficiência do ASM na proteção contra Crinipellis perniciosa em mudas de cacaueiros.

Silva, R. (2002) demonstrou que a aplicação de ASM resultou em redução de incidência de podridão mole causada por Erwinia carotovora em cenoura de $50 \%$ a $90 \%$, quando comparada à testemunha inoculada, não tratada com o produto.

Rizzo et al. (2003) estudaram o efeito do ASM, isolado e em combinação com fungicidas, no controle do cancro da haste em melão rendilhado, causado por Didymella bryoniae. Além das combinações de ASM com difenoconazole, azoxystrobin alternado com chlorothalonil e apenas chlorothalonil, e da aplicação do ASM isoladamente, utilizou-se o benomyl sem adição do indutor. Comparativamente à testemunha inoculada não tratada, os produtos que proporcionaram redução significativa na severidade da doença foram o ASM associado ao difenoconazole e o benomyl. As autoras ressaltam a importância da utilização dessa combinação de produtos para o controle, uma vez que o benomyl não é mais comercializado atualmente.

Ativadores de defesa podem aumentar a resistência a doenças causadas por Phytophthora spp. em morangueiros. Eikemo et al. (2003) observaram que tanto ASM quanto quitosana reduziram os sintomas das doenças causadas por tais fungos na cultura. A inoculação da plantas com $P$. fragarie var. fragarie após o tratamento 
com esses produtos mostrou que o ASM proporcionou bom controle, enquanto para quitosana não teve efeito. Experimentos in vitro mostraram que esses produtos têm pouco ou nenhum efeito sobre 0 crescimento micelial do fungo.

Em solanáceas, o ASM pode induzir resistência contra uma ampla gama de patógenos.

Benhamou \& Belanger (1998) observaram que o tratamento de plantas de tomate com o ASM proporcionou proteção contra a podridão radicular causada pelo fungo Fusarium oxysporum f. sp. radicis-lycopersici.

Anfoka (2000) constatou a proteção de tomateiros contra a infecção pelo vírus Cucumber mosaic virus (CMV) através do emprego de indutor de resistência junto às raízes de plantas jovens de tomate. A redução da incidência da virose nas plantas tratadas com ASM foi de aproximadamente nove vezes, provavelmente devido à translocação do produto até as folhas superiores, ativando genes de resistência envolvidos na replicação viral.

Louws et al. (2001) verificaram que o ASM reduziu a severidade da mancha bacteriana e da pinta bacteriana em tomateiro, causadas por Xanthomonas axonopodis pv. vesicatoria (Xav) e Pseudomonas syringae pv. tomato (Pst), respectivamente, proporcionando controle similar ou superior àquele obtido no sistema padrão à base de cobre e antibiótico. Houve uma redução na incidência dessas doenças nos frutos, mas o rendimento não foi afetado pelo emprego do ativador no campo, quando complementado com fungicidas para manejo de doenças fúngicas foliares. Em casa de vegetação, o emprego de ASM reduziu a densidade populacional de Xav nas folhas, mas, no campo, as populações das duas bactérias não 
foram drasticamente afetadas. Resultados semelhantes foram obtidos por Romero et al. (2001) em plantas de pimentão tratadas com ASM. Esses autores observaram que a aplicação desse produto, no campo, isolado ou em mistura com cobre, resultou em controle da mancha bacteriana semelhante ao proporcionado pela utilização da mistura de cobre e maneb. Ainda com relação à mancha bacteriana em plantas de tomate e pimentão, Abbasi et al. (2002) observaram que o tratamento com ASM resultou em redução significativa da severidade dessa doença nas folhas e nos frutos de plantas inoculadas. Assim como Louws et al. (2001), esses autores também verificaram que o ASM teve pouco ou nenhum efeito sobre a população bacteriana nas folhas tratadas.

No Brasil, diversas pesquisas confirmam a eficiência do emprego do ASM no controle de doenças em solanáceas.

Na cultura da batata, Denardin et al. (2002) observaram significativas reduções na incidência de Erwinia carotovora subsp. carotovora em plantas tratadas com ASM. Estas reduções foram da ordem de $20 \%$ a $50 \%$ em relação a outros tratamentos químicos (Riconil, Agrimicina e Tecto) e à testemunha.

Para a cultura do tomate, há vários relatos da proteção contra patógenos bacterianos, porém o efeito do indutor contra fungos, vírus e nematóides também foi constatado.

Paradela et al. (2002) e Azevedo \& Arruda (2002) verificaram uma resposta positiva das plantas ao tratamento com ASM, em relação à indução de resistência contra o complexo bacteriano (Xanthomonas spp., Pseudomonas spp. e Clavibacter spp.). Não foi estudado o efeito do indutor sobre cada bactéria isoladamente. Paradela et al. (2002) constataram um controle mais 
eficiente do complexo bacteriano quando o ASM foi aplicado em mistura com difenoconazole e pymetrozine. Esses dois trabalhos mencionam uma eficiência do ASM em controlar viroses e vetores de fitoviroses do tomateiro.

Silva et al. (2001) aplicaram ASM em plantas de tomate, via pulverização e rega do solo, e observaram reduções significativas na incidência e na severidade de murcha bacteriana causada por Ralstonia solanacearum, independente do modo de aplicação do produto. No entanto, Araújo et al. (2002) obtiveram melhores resultados na redução da doença, através da aplicação do ASM via pulverização das plantas em comparação com a rega do solo.

Castro et al. (2001) adicionaram o tratamento com ASM ao programa padrão de pulverizações dos agricultores de cinco regiões produtoras e observaram que o indutor proporcionou significativa redução nos sintomas de requeima (Phytophthora infestans), pinta preta (Alternaria solani), septoriose (Septoria lycopersici) e mancha bacteriana (Xanthomonas spp.), e incrementos na produção e na qualidade dos frutos em relação ao programa padrão do produtor.

Em ensaios in vitro, Kobayasti et al. (2001) não observaram efeito direto do ASM sobre as bactérias Xanthomonas axonopodis pv. vesicatoria, Ralstonia solanacearum e Pseudomonas syringae pv. tomato.

Com relação ao efeito do ASM na proteção contra nematóide, Silva et al. (2002a,b) observaram reduções significativas no número de galhas/grama de raiz e na massa de ovos de Meloydogine sp. em tomateiros, em tratamentos contendo o indutor de resistência. 
Os trabalhos anteriormente relatados comprovam que a resistência adquirida se mostra como uma alternativa promissora de controle, uma vez que é inespecífica e pode auxiliar no manejo de várias doenças na mesma cultura, constituindo, dessa forma, uma linha de pesquisa a ser explorada. 


\section{MATERIAL E MÉTODOS}

Os ensaios foram realizados nos laboratórios e telados do Setor de Fitopatologia do Departamento de Entomologia, Fitopatologia e Zoologia Agrícola, da Escola Superior de Agricultura "Luiz de Queiroz", em Piracicaba, São Paulo.

\subsection{Origem, cultivo e preservação do isolado bacteriano}

O isolado de Clavibacter michiganensis subsp. michiganensis $(\mathrm{Cmm})$ foi obtido a partir de plantas de tomate sintomáticas, provenientes de Bragança Paulista, São Paulo. Para a realização dos ensaios, o isolado foi cultivado em meio de cultura nutriente-ágar (NA: extrato de carne - 3,0 g; peptona - 5,0 g; ágar 20,0 g; água destilada - qsp $1000 \mathrm{~mL}$ ), com o pH ajustado para 6,87,0 .

Plantas de tomate da variedade Santa Clara cultivadas em vasos de $0,5 \mathrm{~L}$, contendo substrato esterilizado composto de solo, esterco de curral e areia, na proporção $1: 1: 1$, foram inoculadas com o isolado para comprovação da patogenicidade. Antes da inoculação, as plantas foram mantidas em câmara úmida por 24 horas. A inoculação foi efetuada através de pulverização de suspensão bacteriana voltada para a face inferior das folhas, até o ponto de escorrimento. Após a inoculação, as plantas permaneceram em câmara úmida por 24 horas, 
sendo depois, mantidas em telado. $O$ isolado foi considerado patogênico quando as plantas inoculadas manifestaram os sintomas da doença. Este isolado foi, então, reisolado em meio NA e submetido ao teste de Gram.

Para a preservação, o isolado foi cultivado em meio NA, em tubos de ensaio, durante 48 horas a $28 \pm 1^{\circ} \mathrm{C}$. Após esse período, as culturas bacterianas foram cobertas com óleo mineral esterilizado, até uma altura de aproximadamente $2,0 \mathrm{~cm}$ acima do meio de cultura. Os tubos foram fechados com tampões de algodão, vedados com filme plástico e armazenados, na posição vertical, à temperatura ambiente.

\subsection{Instalação dos ensaios}

Os experimentos de telado foram conduzidos em três etapas distintas, porém com alguns procedimentos experimentais comuns, descritos a seguir.

\subsubsection{Obtenção das plantas hospedeiras}

Buscando-se uma uniformidade das plantas hospedeiras, sementes de tomate, de cada genótipo utilizado, foram semeadas em bandejas de poliestireno de 128 células, contendo substrato agrícola Plantmax $^{\circledR}$ (Eucatex).

Para os experimentos de metodologia de inoculação, referentes à primeira etapa desse trabalho, ao atingirem a idade estabelecida em cada ensaio, as mudas foram transplantadas para sacos plásticos com capacidade de $0,5 \mathrm{~L}$, contendo substrato esterilizado composto de solo, esterco de curral e areia, na proporção 
de $1: 1: 1$, deixando-se duas mudas/saco. Para as etapas subseqüentes, envolvendo reação de genótipos de tomateiro à bactéria e efeito de produtos químicos no controle da doença, as mudas foram transplantadas para sacos plásticos com capacidade de $1,0 \mathrm{~L}$ e foram mantidas três mudas/saco. As plantas permaneceram em telado até o término dos experimentos.

\subsubsection{Obtenção do inóculo bacteriano}

Para a obtenção do inóculo a partir de colônia pura, o isolado bacteriano foi repicado para placas de Petri contendo meio NA e incubado à temperatura de $28 \pm 1^{\circ} \mathrm{C}$, por 48 horas. Após 0 desenvolvimento das colônias, foram preparadas suspensões bacterianas em água destilada, ajustando-se a concentração para $3 \mathrm{x}$ $10^{8} \mathrm{ufc} / \mathrm{mL}$, em espectrofotômetro (65\% de transmitância a um comprimento de onda de $550 \mathrm{~nm}$ ). Posteriormente, as suspensões foram diluídas de modo a conter as concentrações de inóculo estabelecidas em cada ensaio.

\subsubsection{Avaliação dos ensaios}

As avaliações foram feitas em função do número de plântulas murchas ou mortas, através de leituras diárias de acordo com uma escala de notas adaptada, variando de 1 a 5 (Nielsen \& Haynes Junior, 1960), com a seguinte correspondência: 1 = ausência de sintomas; 2 = planta com $1 / 3$ das folhas murchas; $3=$ planta com $2 / 3$ das folhas murchas; $4=$ planta totalmente murcha; $5=$ planta morta. 
As leituras obtidas foram transformadas em índice de murcha bacteriana (Empig et al. citados por Morgado et al., 1992), através da equação:

$$
\mathrm{IMB}=\sum(\mathrm{C} \times \mathrm{P} / \mathrm{N})
$$

onde, $\mathrm{IMB}=$ índice de murcha bacteriana; $\mathrm{C}=$ nota atribuída a cada classe de sintomas; $\mathrm{P}=$ número de plântulas em cada classe de sintoma; e $\mathrm{N}=$ número total de plântulas inoculadas.

\subsection{ETAPA I: Metodologia de inoculação de Clavibacter michiganensis subsp. michiganensis em tomateiro}

Essa etapa foi constituída de dois ensaios, sendo cada um deles realizado em duplicata, e teve por objetivo determinar uma metodologia de inoculação adequada para a realização de estudos relacionados ao patossistema Lycopersicon esculentum - Clavibacter michiganensis subsp. michiganensis.

\subsubsection{Ensaio I: Comparação entre diversos métodos de inoculação associados a diferentes concentrações de inóculo bacteriano}

Nesse ensaio, constituído pelos experimentos 1 e 2, foram empregados os genótipos de tomate Rotam-4 e Kadá, considerados resistente e suscetível ao cancro bacteriano, respectivamente. As temperaturas médias registradas durante a condução dos experimentos 1 e 2 variaram de 19,3 a $32,8^{\circ} \mathrm{C}$ e 19,1 a $32,6^{\circ} \mathrm{C}$, respectivamente. 
Os métodos de inoculação utilizados foram:

$M_{1}=$ aspersão da suspensão bacteriana na face inferior da folha até o ponto de escorrimento;

$M_{2}$ = aspersão da suspensão bacteriana sob pressão, na face inferior da folha, até o ponto de escorrimento;

$\mathrm{M}_{3}=$ corte do sistema radicular com tesoura, seguido de imersão das raízes na suspensão bacteriana (Lopes, 1981), conforme esquema da Figura 1; e

$M_{4}=$ ferimento na haste causado pela introdução de um alfinete entomológico número 3 transpassando uma gota de $10 \mu \mathrm{L}$ da suspensão do inóculo, depositada na axila foliar (Morgado et al., 1992), conforme esquematizado na Figura 2.

Para cada método testado, foram utilizadas suspensões bacterianas com as seguintes concentrações de inóculo:

$\mathrm{C}_{1}=10^{8} \mathrm{ufc} / \mathrm{mL}$;

$\mathrm{C}_{2}=10^{7} \mathrm{ufc} / \mathrm{mL}$;

$\mathrm{C}_{3}=10^{6} \mathrm{ufc} / \mathrm{mL} ; \mathrm{e}$

$\mathrm{C}_{4}=$ tratamento testemunha (plantas tratadas com água destilada).

As plantas foram inoculadas quatorze dias após a emergência, dois dias após terem sido transplantadas para os sacos plásticos. Antes da inoculação, as plantas foram mantidas em câmaras úmidas constituídas de sacos plásticos, por 24 horas. Após a inoculação, as plantas permaneceram em câmara úmida por 24 horas.

0 ensaio foi instalado segundo o esquema fatorial $2 \times 4 \times 4$ (2 genótipos $\times 4$ métodos de inoculação $\times 4$ concentrações de inóculo), de acordo com o delineamento inteiramente casualizado, com três repetições, sendo a parcela experimental constituída por três sacos, com duas plantas/saco. 

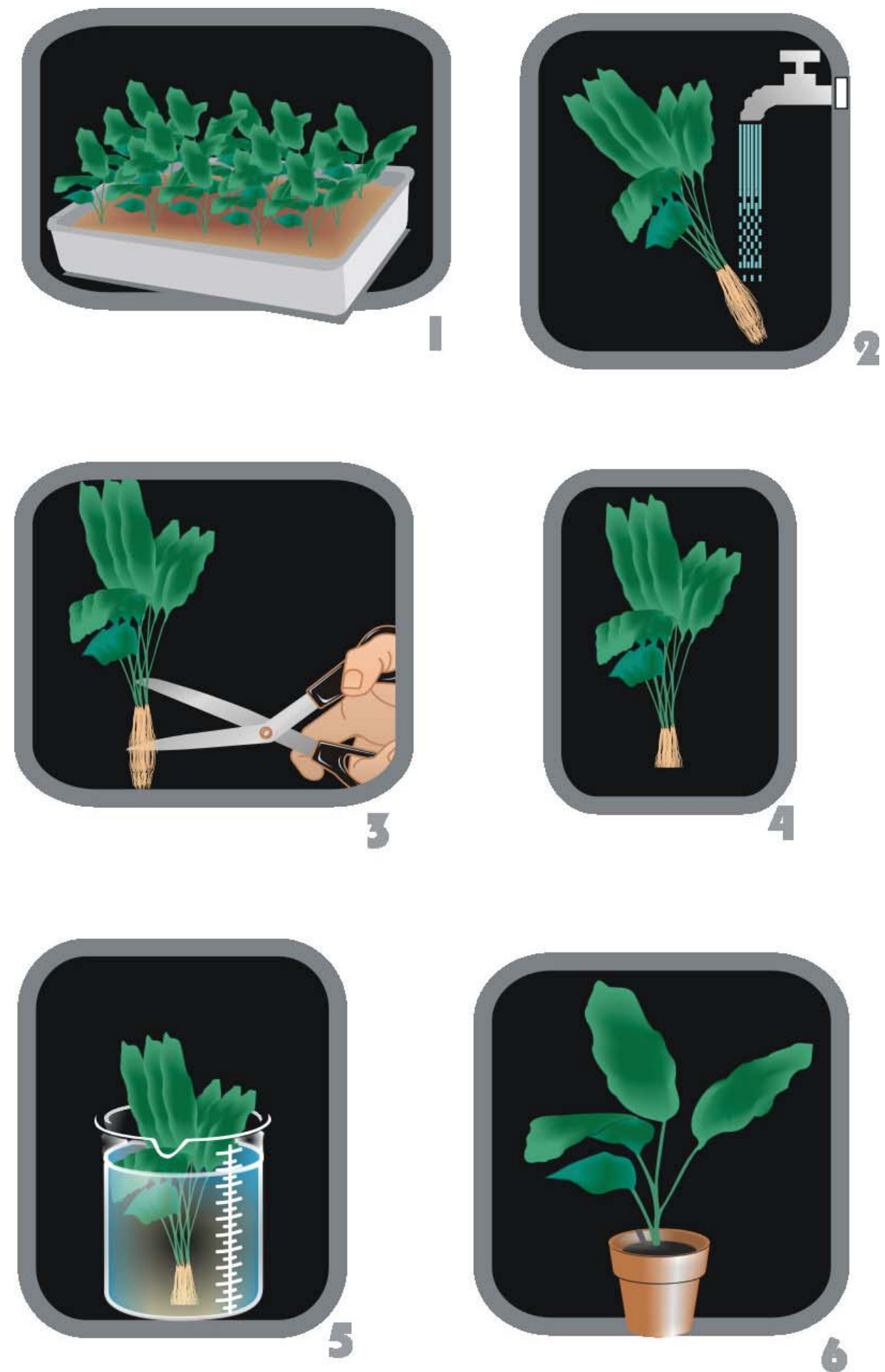

Figura 1 - Esquema de inoculação do sistema radicular de tomateiros com Clavibacter michiganensis subsp. michiganensis, adaptado de Lopes (1981) 

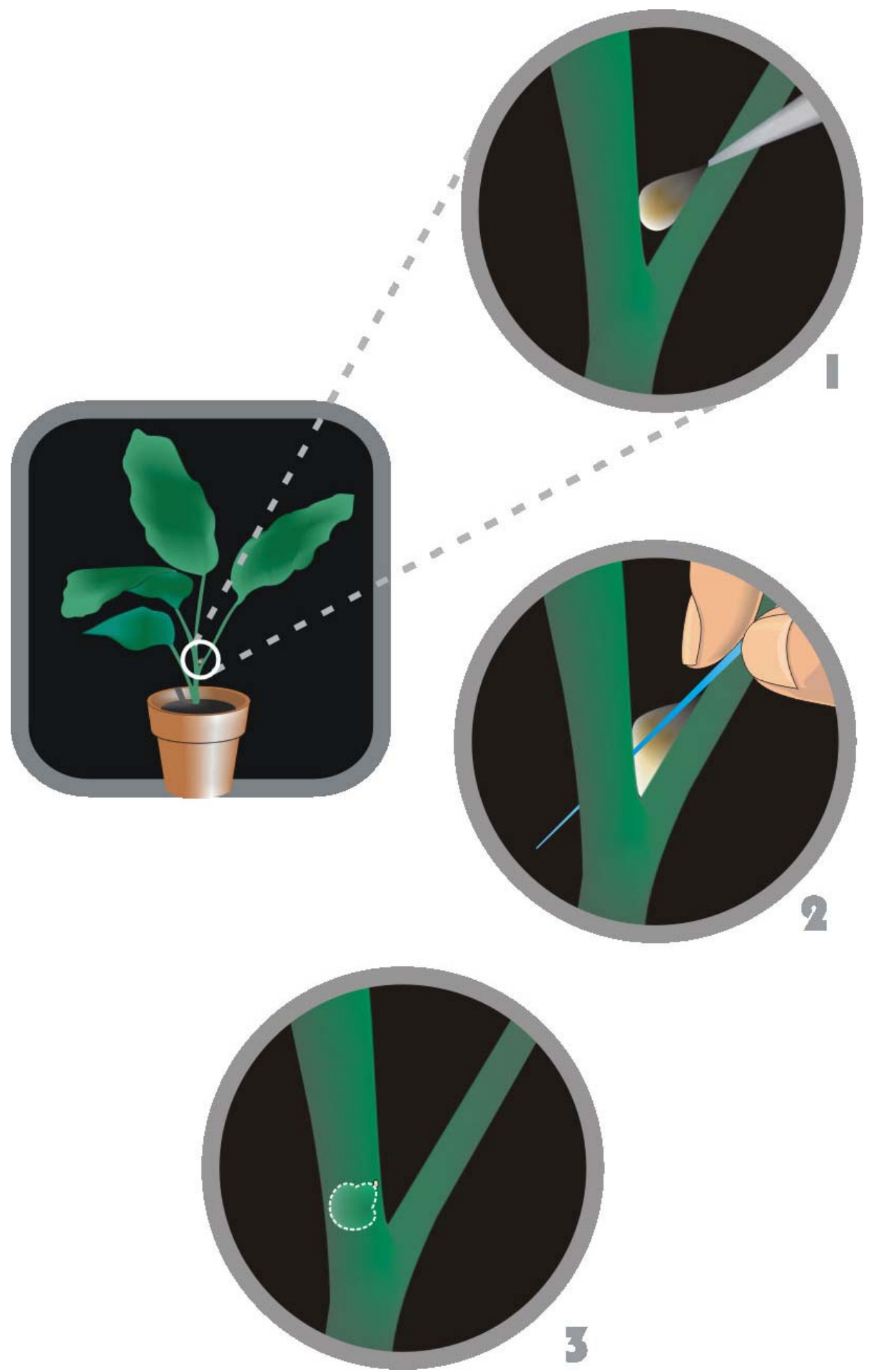

Figura 2 - Esquema de inoculação de Clavibacter michiganensis subsp. michiganensis em tomateiros, através de ferimento na haste, adaptado de Morgado et al. (1994) 
A avaliação dos experimentos foi realizada conforme descrito em 3.2.3. A análise estatística foi realizada com os dados de IMB provenientes das leituras aos 21, 30 e 35 dias após a inoculação.

A análise de variância foi feita pelo teste $F$ e as médias, comparadas pelo teste de Tukey a $5 \%$ de probabilidade.

\subsubsection{Ensaio II: Efeito da idade da planta de tomate sobre o desenvolvimento do cancro bacteriano}

Esse ensaio, também constituído de dois experimentos distintos (experimento 3 e experimento 4), foi instalado com o objetivo de determinar o efeito da idade da planta no momento da inoculação sobre a manifestação dos sintomas da doença. Os dois experimentos foram conduzidos sob condições de temperatura variando de 16,6 a $25,9^{\circ} \mathrm{C}$.

Para a realização deste ensaio, foram utilizados os genótipos Kadá (suscetível) e Rotam-4 (resistente).

Para a inoculação das plantas, foi empregado o método de aspersão da suspensão bacteriana na face inferior da folha até o ponto de escorrimento, na concentração de $10^{8} \mathrm{ufc} / \mathrm{mL}$.

As plantas foram inoculadas com as seguintes idades:

$\mathrm{I}_{1}=7$ dias após a emergência;

$\mathrm{I}_{2}=14$ dias após a emergência;

$\mathrm{I}_{3}=21$ dias após a emergência; e

$\mathrm{I}_{4}=28$ dias após a emergência.

Antes e depois da inoculação, as plantas permaneceram em câmaras úmidas individuais, por 24 horas. 
O ensaio foi instalado no delineamento experimental inteiramente casualizado com oito tratamentos ( 2 cultivares e 4 idades) e três repetições, sendo a parcela experimental constituída por três sacos, com duas plantas/saco.

As plantas foram avaliadas conforme descrito em 3.2.3. A análise estatística foi realizada com os dados de IMB obtidos nas leituras aos 30 e 40 dias após a inoculação.

A análise de variância foi feita pelo teste $F$ e as médias, comparadas pelo teste de Tukey a $5 \%$ de probabilidade.

\subsection{ETAPA II: Reação de genótipos de tomateiro à inoculação com Clavibacter michiganensis subsp. michiganensis}

Dez genótipos comerciais de tomateiro (Carmen, Débora max, IPA-6, Santa Clara, Alambra, Júpiter, Olimpo, Fanny, Jumbo e Densus) foram avaliados para a resistência ao cancro bacteriano. Kadá e Rotam-4 foram empregados como controle suscetível e resistente, respectivamente. As temperaturas médias observadas variaram de 19,6 a $32,0^{\circ} \mathrm{C}$.

As mudas foram obtidas conforme descrito em 3.2.1 e o transplante foi realizado doze dias após a emergência. Quatorze dias após a emergência, as plantas foram inoculadas através de aspersão da suspensão bacteriana $\left(10^{8} \mathrm{ufc} / \mathrm{mL}\right)$ na face inferior da folha, até o ponto de escorrimento. As plantas foram submetidas à câmara úmida durante 24 horas antes e 24 horas depois da inoculação.

O delineamento experimental utilizado foi o inteiramente casualizado, com doze tratamentos (genótipos) e três repetições, 
sendo a parcela experimental constituída por dois sacos, com três plantas/saco.

O experimento foi avaliado conforme descrito em 3.2.3. A análise estatística foi realizada com os dados de IMB obtidos na leitura realizada aos 30 dias após a inoculação.

A análise de variância foi feita pelo teste $F$ e as médias, comparadas pelo teste de Tukey a $5 \%$ de probabilidade.

\subsection{ETAPA III: Controle do cancro bacteriano do tomateiro através do emprego de produtos químicos}

A presente etapa foi constituída de um ensaio conduzido em telado e de teste de laboratório para averiguar o efeito de produtos químicos no controle da doença e possível ação destes sobre a bactéria.

\subsubsection{Efeito do acibenzolar-S-metil e outros produtos fitossanitários no controle do cancro bacteriano do tomateiro em condições de telado}

O experimento foi conduzido sob condições de temperatura variando de 19,6 a $32,0^{\circ} \mathrm{C}$.

Plantas de tomate da cultivar Santa Clara, suscetível ao cancro bacteriano, foram obtidas conforme descrito em 3.2.1 e transplantadas uma semana após a emergência. Plantas com quatorze dias após a emergência foram inoculadas através da aspersão de suspensão bacteriana $\left(10^{8} \mathrm{ufc} / \mathrm{mL}\right)$ na face inferior das 
folhas, até o ponto de escorrimento. As plantas foram mantidas em câmara úmida por 24 horas, antes e depois da inoculação.

As seguintes combinações de produtos químicos foram utilizadas:

$P_{1}=\operatorname{ASM}(2,5$ g i.a./100 L de água);

$P_{2}=\operatorname{ASM}(2,5$ g i.a./100 L de água) + mancozeb (240 g i.a./100 L de água);

$\mathrm{P}_{3}=\operatorname{ASM}(2,5 \mathrm{~g}$ i.a. $/ 100 \mathrm{~L}$ de água $)+$ oxicloreto de cobre $(110 \mathrm{~g}$ i.a./100 L de água);

$\mathrm{P}_{4}=$ mancozeb (240 g i.a./100 L de água) + oxicloreto de cobre (110 g i.a./100 L de água);

$\mathrm{P}_{5}=$ oxitetraciclina (100 g i.a./100 L de água).

Três esquemas de aplicação dos produtos foram adotados:

$E_{1}=4$ aplicações. A primeira e a segunda aplicações foram realizadas seis e três dias antes da inoculação, respectivamente; a terceira e a quarta aplicações foram realizadas três e seis dias após a inoculação.

$E_{2}=$ apenas as duas aplicações pré-inoculação.

$\mathrm{E}_{3}=$ apenas as duas aplicações pós-inoculação.

Os produtos foram aplicados através de pulverização na parte aérea das plantas.

Um tratamento testemunha, constituído de plantas inoculadas com suspensão bacteriana sem a aplicação dos produtos, foi incluído no ensaio.

O experimento foi instalado no esquema fatorial $5 \times 3$ (5 combinações de produtos e 3 esquemas de aplicação), com 15 tratamentos e uma testemunha. O delineamento experimental foi 0 inteiramente casualizado, com três repetições. A parcela experimental foi constituída por dois sacos, com três plantas/saco. 
O experimento foi avaliado conforme descrito em 3.2.3. A análise estatística foi realizada com os dados de IMB obtidos na leitura realizada aos 30 dias após a inoculação.

A análise de variância foi feita pelo teste F. A média do tratamento testemunha foi comparada com a média de cada um dos demais tratamentos pelo teste de Dunnett a $5 \%$ de probabilidade. As médias dos demais tratamentos foram comparadas entre si pelo teste de Tukey a $5 \%$ de probabilidade.

\subsubsection{Efeito in vitro do acibenzolar-S-metil e outros produtos fitossanitários sobre Clavibacter michiganensis subsp. michiganensis.}

Os produtos utilizados no experimento realizado em telado tiveram seus efeitos sobre $\mathrm{Cmm}$ avaliados in vitro.

Para a realização do ensaio, a bactéria foi isolada a partir de folhas de plantas de tomate cultivar Santa Clara, do tratamento testemunha (inoculado e não tratado) do experimento conduzido em telado. A bactéria isolada foi cultivada em meio NA e incubada a $28^{\circ} \mathrm{C}$ por 48 horas. A massa bacteriana coletada com uma alça de platina de $3 \mathrm{~mm}$ de diâmetro foi dissolvida em $10 \mathrm{~mL}$ de água destilada esterilizada, para a obtenção de suspensão bacteriana. Alíquotas de 5 $\mu L$ dessa suspensão foram depositadas em três pontos eqüidistantes sobre o meio NA suplementado com ASM; ASM + mancozeb; ASM + oxicloreto de cobre; mancozeb; oxicloreto de cobre; e oxitetraciclina, nas concentrações de 100 e 1000 ppm. Os produtos foram adicionados assepticamente ao meio de cultura, no momento que este foi vertido nas placas de Petri. Concomitantemente, a viabilidade da 
bactéria foi avaliada em meio NA não suplementado com os produtos químicos.

O teste foi avaliado após um período de incubação de 96 horas a $28^{\circ} \mathrm{C}$, observando-se a ocorrência ou não de crescimento bacteriano sobre os meios. 


\section{RESULTADOS}

\subsection{ETAPA I: Metodologia de inoculação de Clavibacter michiganensis subsp. michiganensis em tomateiro}

\subsubsection{Ensaio I: Comparação entre diversos métodos de inoculação associados a diferentes concentrações de inóculo bacteriano}

As médias gerais de Índice de Murcha Bacteriana (IMB) para genótipos $(G)$, métodos de inoculação $(M)$ e concentrações de inóculo $(C)$, obtidas nas três leituras dos experimentos 1 e 2, bem como os resultados do teste $F$ e os valores dos coeficientes de variação estão apresentados na tabela 1.

A leitura realizada aos 30 dias após a inoculação mostrouse a mais apropriada aos objetivos do trabalho e foi a data de avaliação adotada para as etapas posteriores da pesquisa.

Para a referida leitura, nos dois experimentos, todas as interações duplas foram significativas, indicando haver dependência entre os fatores, ou seja, genótipos, métodos de inoculação e concentrações de inóculo não podem ser analisados isoladamente. Por esse motivo, procedeu-se o desdobramento dessas interações e os resultados desses desdobramentos estão apresentados nas tabelas 2 (interação $G \times M$ ), 3 (interação $G \times C$ ) e 4 (interação $M \times C$ ). 
Tabela 1. Médias gerais de Índice de Murcha Bacteriana (IMB) para genótipos, métodos de inoculação e concentrações de inóculo, nas três leituras dos experimentos 1 e 2, resultados do teste $\mathrm{F}$ e coeficiente de variação. Piracicaba, 2003

\begin{tabular}{|c|c|c|c|c|c|c|}
\hline \multirow{2}{*}{ Fatores } & \multicolumn{3}{|c|}{ Experimento 1} & \multicolumn{3}{|c|}{ Experimento 2} \\
\hline & $1^{\text {a leitura }}$ & $2^{\mathrm{a}}$ leitura & $3^{a}$ leitura & $1^{\text {a }}$ leitura & $2^{\mathrm{a}}$ leitura & $3^{a}$ leitura \\
\hline \multicolumn{7}{|l|}{ Genótipos (G): } \\
\hline Kadá & 1,185 & 1,347 & 1,548 & 1,209 & 1,288 & 1,465 \\
\hline Rotam-4 & 1,049 & 1,124 & 1,221 & 1,067 & 1,122 & 1,236 \\
\hline \multicolumn{7}{|l|}{ Métodos de } \\
\hline \multicolumn{7}{|l|}{ Inoculação (M): } \\
\hline Aspersão & 1,168 & 1,375 & 1,625 & 1,173 & 1,271 & 1,486 \\
\hline Aspersão sob pressão & 1,090 & 1,191 & 1,330 & 1,182 & 1,237 & 1,396 \\
\hline Ferimento na haste & 1,056 & 1,125 & 1,209 & 1,056 & 1,111 & 1,250 \\
\hline Imersão de raiz & 1,168 & 1,250 & 1,375 & 1,140 & 1,202 & 1,270 \\
\hline \multicolumn{7}{|l|}{$\begin{array}{l}\text { Concentrações } \\
\text { de Inóculo (C): }\end{array}$} \\
\hline $10^{8} \mathrm{ucf} / \mathrm{mL}$ & 1,292 & 1,506 & 1,785 & 1,258 & 1,382 & 1,645 \\
\hline $10^{7} \mathrm{ucf} / \mathrm{mL}$ & 1,119 & 1,253 & 1,427 & 1,182 & 1,271 & 1,424 \\
\hline $10^{6} \mathrm{ucf} / \mathrm{mL}$ & 1,056 & 1,182 & 1,326 & 1,112 & 1,168 & 1,333 \\
\hline Testemunha & 1,000 & 1,000 & 1,000 & 1,000 & 1,000 & 1,000 \\
\hline \multicolumn{7}{|l|}{ Teste F: } \\
\hline Genótipos (G) & $21,24 * *$ & $67,66 * *$ & $76,18 * *$ & $64,28 * *$ & $64,67 * *$ & $39,81 * *$ \\
\hline $\begin{array}{l}\text { Métodos de } \\
\text { Inoculação (M) }\end{array}$ & $3,19 *$ & $15,35 * *$ & $21,72 * *$ & $10,51 * *$ & $11,05^{* *}$ & $9,35^{* *}$ \\
\hline $\begin{array}{l}\text { Concentrações } \\
\text { de Inóculo(C) }\end{array}$ & $18,43 * *$ & $59,79 * *$ & $74,12 * *$ & $38,22 * *$ & $61,87 * *$ & $54,28 * *$ \\
\hline Interação G x M & $0,84^{\mathrm{NS}}$ & $8,52 * *$ & $11,02 * *$ & $0,59^{\mathrm{NS}}$ & $3,69 *$ & $6,26 * *$ \\
\hline Interação G x C & $4,83 *$ & $23,24 * *$ & $21,80 * *$ & $11,73 * *$ & $14,20 * *$ & $11,51 * *$ \\
\hline Interação $M \times C$ & $0,86^{\mathrm{NS}}$ & $6,24 * *$ & $8,98 * *$ & $2,48^{*}$ & $2,59 *$ & $1,73^{\mathrm{NS}}$ \\
\hline Interação $\mathrm{G} \times \mathrm{M} \times \mathrm{C}$ & $0,39^{\mathrm{NS}}$ & $6,15^{* *}$ & $6,33 * *$ & $1,47^{\mathrm{NS}}$ & $1,23^{\mathrm{NS}}$ & $1,71^{\mathrm{NS}}$ \\
\hline $\begin{array}{l}\text { Coeficiente de } \\
\text { Variação }(\%)\end{array}$ & 12,93 & 10,76 & 13,29 & 7,62 & 8,39 & 13,19 \\
\hline \multicolumn{7}{|c|}{$\begin{array}{l}\text { NS - não significativo }(P>0,05) \\
* \text { - significativo }(P<0,05) \\
* * \text { - significativo }(P<0,01)\end{array}$} \\
\hline \multicolumn{7}{|c|}{ 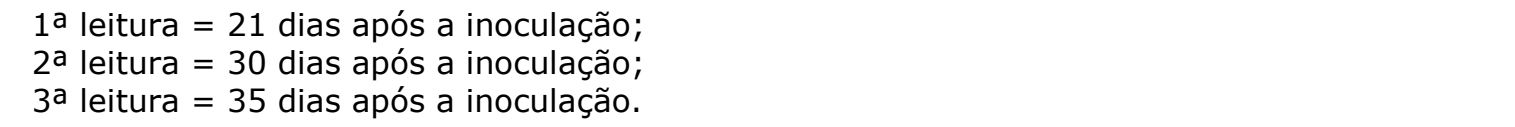 } \\
\hline
\end{tabular}


Tabela 2. Efeito de genótipos e métodos de inoculação sobre o Índice de Murcha Bacteriana (IMB) avaliado aos 30 dias após a inoculação com Clavibacter michiganensis subsp. michiganensis. Piracicaba, 2003

\begin{tabular}{llcccc}
\hline Genótipo & Método de Inoculação & Experimento 1 & \multicolumn{2}{c}{ Experimento 2} \\
\hline \multirow{4}{*}{ Kadá } & Aspersão & $1,598 \mathrm{a}$ & $\mathrm{A}$ & $1,403 \mathrm{a}$ & $\mathrm{A}$ \\
& Aspersão sob pressão & $1,263 \mathrm{bc}$ & $\mathrm{A}$ & $1,333 \mathrm{ab}$ & $\mathrm{A}$ \\
& Ferimento na haste & $1,166 \mathrm{c}$ & $\mathrm{A}$ & $1,153 \mathrm{c}$ & $\mathrm{A}$ \\
& Imersão de raiz & $1,361 \mathrm{~b}$ & $\mathrm{~A}$ & $1,264 \mathrm{~b}$ & $\mathrm{~A}$ \\
& Aspersão & $1,153 \mathrm{a}$ & $\mathrm{B}$ & $1,139 \mathrm{a}$ & $\mathrm{B}$ \\
\multirow{2}{*}{ Rotam-4 } & Aspersão sob pressão & $1,118 \mathrm{a}$ & $\mathrm{B}$ & $1,140 \mathrm{a}$ & $\mathrm{B}$ \\
& Ferimento na haste & $1,085 \mathrm{a}$ & $\mathrm{A}$ & $1,070 \mathrm{a}$ & $\mathrm{A}$ \\
& Imersão de raiz & $1,138 \mathrm{a}$ & $\mathrm{B}$ & $1,139 \mathrm{a}$ & $\mathrm{B}$
\end{tabular}

Em cada coluna:

a,b - para cada Genótipo, médias de Métodos de Inoculação seguidas de mesma letra minúscula não diferem entre si $(P>0,05)$.

A,B - para cada Método de Inoculação, médias de Genótipos seguidas de mesma letra maiúscula não diferem entre si $(P>0,05)$.

Para o genótipo Kadá, os maiores valores de IMB foram observados para a inoculação por aspersão, apesar deste método não ter diferido significativamente do método de aspersão sob pressão, no experimento 2. O método de ferimento na haste proporcionou os menores IMB, nos dois experimento. Para Rotam-4, não houve diferença significativa entre os métodos, nos dois experimentos.

Para os métodos de inoculação testados, os valores de IMB obtidos para Kadá foram significativamente superiores aos obtidos para Rotam-4, exceto para a inoculação na haste, que não revelou diferença de resposta entre os genótipos. 
Tabela 3. Efeito de genótipos e concentrações de inóculo sobre o Índice de Murcha Bacteriana (IMB) avaliado aos 30 dias após a inoculação com Clavibacter michiganensis subsp. michiganensis. Piracicaba, 2003

\begin{tabular}{cccccc}
\hline Genótipo & $\begin{array}{c}\text { Concentração } \\
\text { de Inóculo }\end{array}$ & Experimento 1 & Experimento 2 \\
\hline \multirow{3}{*}{ Kadá } & $10^{8} \mathrm{ufc} / \mathrm{mL}$ & $1,804 \mathrm{a}$ & $\mathrm{A}$ & $1,570 \mathrm{a}$ & $\mathrm{A}$ \\
& $10^{7} \mathrm{ufc} / \mathrm{mL}$ & $1,353 \mathrm{~b}$ & $\mathrm{~A}$ & $1,347 \mathrm{~b}$ & $\mathrm{~A}$ \\
& $10^{6} \mathrm{ufc} / \mathrm{mL}$ & $1,230 \mathrm{~b}$ & $\mathrm{~A}$ & $1,236 \mathrm{c}$ & $\mathrm{A}$ \\
& Testemunha & $1,000 \mathrm{c}$ & $\mathrm{A}$ & $1,000 \mathrm{~d}$ & $\mathrm{~A}$ \\
& $10^{8} \mathrm{ufc} / \mathrm{mL}$ & $1,208 \mathrm{a}$ & $\mathrm{B}$ & $1,194 \mathrm{a}$ & $\mathrm{B}$ \\
& $10^{7} \mathrm{ufc} / \mathrm{mL}$ & $1,153 \mathrm{a}$ & $\mathrm{B}$ & $1,195 \mathrm{a}$ & $\mathrm{B}$ \\
Rotam-4 & $10^{6} \mathrm{ufc} / \mathrm{mL}$ & $1,133 \mathrm{ab}$ & $\mathrm{A}$ & $1,099 \mathrm{ab}$ & $\mathrm{B}$ \\
& Testemunha & $1,000 \mathrm{~b}$ & $\mathrm{~A}$ & $1,000 \mathrm{~b}$ & $\mathrm{~A}$ \\
\hline
\end{tabular}

Em cada coluna:

a,b - para cada Genótipo, médias de Concentrações de Inóculo seguidas de mesma letra minúscula não diferem entre si $(P>0,05)$.

A,B - para cada Concentração de Inóculo, médias de Genótipos seguidas de mesma letra maiúscula não diferem entre si $(P>0,05)$.

Para Kadá, a concentração de inóculo de $10^{8}$ ufc/mL resultou em valores de IMB significativamente superiores, comparativamente às outras concentrações e à testemunha, para os dois experimentos. As concentrações $10^{7}$ e $10^{6} \mathrm{ufc} / \mathrm{mL}$ também diferiram significativamente da testemunha quanto ao IMB. Para Rotam-4, as concentrações $10^{8}$ e $10^{7} \mathrm{ufc} / \mathrm{mL}$ resultaram em IMB superior à testemunha, nos dois experimentos. Os valores de IMB obtidos para a concentração $10^{6} \mathrm{ufc} / \mathrm{mL}$, embora não tenham diferido das outras concentrações, também não diferiram da testemunha.

Para as concentrações $10^{8}$ e $10^{7} \mathrm{ufc} / \mathrm{mL}$, os valores de IMB de Kadá foram significativamente superiores aos de Rotam-4 nos dois 
experimentos. Para a concentração $10^{6} \mathrm{ufc} / \mathrm{mL}$, a diferença entre os genótipos só foi observada no experimento 2 .

Tabela 4. Efeito de métodos de inoculação e concentrações de inóculo sobre o Índice de Murcha Bacteriana (IMB) avaliado aos 30 dias após a inoculação com Clavibacter michiganensis subsp. michiganensis. Piracicaba, 2003

\begin{tabular}{|c|c|c|c|}
\hline $\begin{array}{l}\text { Método de } \\
\text { Inoculação }\end{array}$ & $\begin{array}{l}\text { Concentração } \\
\text { de Inóculo }\end{array}$ & Experimento 1 & Experimento 2 \\
\hline \multirow{4}{*}{ Aspersão } & $10^{8} \mathrm{ufc} / \mathrm{mL}$ & 1,917 a $A$ & 1,472 a $A$ \\
\hline & $10^{7} \mathrm{ufc} / \mathrm{mL}$ & $1,388 \mathrm{~b} \quad \mathrm{~A}$ & $1,333 a b A$ \\
\hline & $10^{6} \mathrm{ufc} / \mathrm{mL}$ & 1,197 bc $A$ & $1,278 \mathrm{~b} \quad \mathrm{~A}$ \\
\hline & Testemunha & $1,000 \mathrm{C} \quad \mathrm{A}$ & $1,000 \mathrm{C} \quad \mathrm{A}$ \\
\hline \multirow{4}{*}{$\begin{array}{c}\text { Aspersão } \\
\text { Sob } \\
\text { Pressão }\end{array}$} & $10^{8} \mathrm{ufc} / \mathrm{mL}$ & 1,388 a $\quad B C$ & 1,418 a $A$ \\
\hline & $10^{7} \mathrm{ufc} / \mathrm{mL}$ & 1,208 ab AB & 1,278 ab A \\
\hline & $10^{6} \mathrm{ufc} / \mathrm{mL}$ & 1,167 bc $A$ & $1,250 \mathrm{~b} \quad \mathrm{~A}$ \\
\hline & Testemunha & $1,000 \mathrm{C} \quad \mathrm{A}$ & $1,000 \mathrm{C} \mathrm{A}$ \\
\hline \multirow{4}{*}{$\begin{array}{c}\text { Ferimento } \\
\text { na haste }\end{array}$} & $10^{8} \mathrm{ufc} / \mathrm{mL}$ & 1,222 a C & 1,195 a $B$ \\
\hline & $10^{7} \mathrm{ufc} / \mathrm{mL}$ & 1,140 ab B & 1,193 a $A$ \\
\hline & $10^{6} \mathrm{ufc} / \mathrm{mL}$ & 1,140 ab A & 1,057 ab B \\
\hline & Testemunha & $1,000 \mathrm{~b} \quad \mathrm{~A}$ & $1,000 \mathrm{~b} \quad \mathrm{~A}$ \\
\hline \multirow{4}{*}{$\begin{array}{l}\text { Imersão } \\
\text { de raiz }\end{array}$} & $10^{8} \mathrm{ufc} / \mathrm{mL}$ & 1,498 a $B$ & 1,443 a $A$ \\
\hline & $10^{7} \mathrm{ufc} / \mathrm{mL}$ & $1,277 b \quad A B$ & $1,278 \mathrm{~b} \quad \mathrm{~A}$ \\
\hline & $10^{6} \mathrm{ufc} / \mathrm{mL}$ & $1,223 \mathrm{~b} \quad \mathrm{~A}$ & $1,085 \mathrm{C} \quad \mathrm{B}$ \\
\hline & Testemunha & $1,000 \mathrm{CA}$ & $1,000 \mathrm{C} \mathrm{A}$ \\
\hline
\end{tabular}

Em cada coluna:

a,b - para cada Método de Inoculação, médias de Concentrações de Inóculo seguidas de mesma letra minúscula não diferem entre si $(P>0,05)$.

A,B - para cada Concentração de Inóculo, médias de Métodos de Inoculação seguidas de mesma letra maiúscula não diferem entre si $(P>0,05)$. 
Para todos os métodos de inoculação adotados, a concentração $10^{8} \mathrm{ufc} / \mathrm{mL}$ resultou em maiores valores de IMB, sendo significativamente superior à testemunha, nos dois experimentos.

Para as concentrações de inóculo testadas, as médias de IMB obtidas para a inoculação por aspersão foram, na maioria dos casos, significativamente superiores àquelas resultantes dos outros métodos, quando utilizadas as concentrações mais altas de inóculo.

Em resumo, os resultados desse ensaio mostraram que, embora tenham ocorrido algumas variações de resposta entre os fatores analisados, a inoculação por aspersão de suspensão bacteriana na parte aérea da planta, na concentração $10^{8} \mathrm{ufc} / \mathrm{mL}$, foi o método que resultou em maiores valores de IMB.

\subsubsection{Ensaio II: Efeito da idade da planta de tomate sobre o desenvolvimento do cancro bacteriano}

Para o presente ensaio, optou-se por considerar os resultados obtidos nas duas leituras, sendo a primeira realizada aos 30 dias após a inoculação, que se mostrou mais apropriada no ensaio anterior, e a segunda, realizada dez dias após a primeira. A opção pela segunda leitura deveu-se ao fato de terem sido registradas, durante a condução desse ensaio, condições de temperatura diferentes daquelas observadas nos experimentos 1 e 2 (ensaio I). As temperaturas médias variaram de 19 a $32^{\circ} \mathrm{C}$ e 16 a $26^{\circ} \mathrm{C}$ para os ensaios I e II, respectivamente. Possíveis efeitos da temperatura sobre o desenvolvimento da doença serão discutidos no item 5.1.

A tabela 5 mostra as médias gerais de IMB para genótipos (G) e idades da planta (I) obtidas nas duas leituras dos experimentos 
3 e 4, assim como os resultados do teste $F$ e os valores dos coeficientes de variação.

Tabela 5. Médias gerais de Índice de Murcha Bacteriana (IMB) para genótipos e idades das plantas obtidas a partir de leituras realizadas aos 30 e 40 dias após a inoculação (d.a.i.), para os experimentos 3 e 4, resultados do teste $F$ e coeficiente de variação. Piracicaba, 2003

\begin{tabular}{|c|c|c|c|c|}
\hline \multirow{2}{*}{ Fatores } & \multicolumn{2}{|c|}{ Experimento 3} & \multicolumn{2}{|c|}{ Experimento 4} \\
\hline & 30 d.a.i. & 40 d.a.i. & 30 d.a.i. & 40 d.a.i. \\
\hline \multicolumn{5}{|l|}{ Genótipos (G): } \\
\hline Kadá & $1,542 \mathrm{~A}$ & $1,737 \mathrm{~A}$ & $1,528 \mathrm{~A}$ & $1,722 \mathrm{~A}$ \\
\hline Rotam-4 & $1,347 \mathrm{~B}$ & $1,472 \mathrm{~B}$ & $1,375 \mathrm{~B}$ & $1,570 \mathrm{~B}$ \\
\hline \multicolumn{5}{|l|}{ Idades das Plantas (I): } \\
\hline 7 dias após emergência & $1,556 \mathrm{a}$ & $1,723 \mathrm{a}$ & $1,444 \mathrm{a}$ & $1,667 a b$ \\
\hline 14 dias após emergência & 1,473 a & $1,750 \mathrm{a}$ & $1,584 a$ & $1,834 \mathrm{a}$ \\
\hline 21 dias após emergência & $1,417 \mathrm{a}$ & $1,528 a b$ & $1,388 a$ & $1,556 a b$ \\
\hline 28 dias após emergência & $1,333 a$ & $1,417 \mathrm{~b}$ & 1,389 a & $1,528 b$ \\
\hline \multicolumn{5}{|l|}{ Teste F: } \\
\hline Genótipos (G) & $7,25 *$ & $18,05^{* *}$ & $6,72 *$ & $4,83^{*}$ \\
\hline Idades das Plantas (I) & $1,68^{\mathrm{NS}}$ & $6,56 * *$ & $2,43^{\mathrm{NS}}$ & $3,98 *$ \\
\hline Interação G x I & $0,45^{\mathrm{NS}}$ & $1,12^{\mathrm{NS}}$ & $1,98^{\mathrm{NS}}$ & $0,78^{\mathrm{NS}}$ \\
\hline Coeficiente de Variação (\%) & 12,26 & 9,50 & 9,95 & 10,35 \\
\hline \multicolumn{5}{|l|}{$\begin{array}{l}\text { NS - não significativo }(P>0,05) \\
* \text { - significativo }(P<0,05) \\
* * \text { - significativo }(P<0,01)\end{array}$} \\
\hline \multicolumn{5}{|c|}{$\begin{array}{l}\text { Em cada coluna: } \\
\text { A,B - médias de Genótipos seguidas de mesma letra maiúscula não diferem } \\
\quad \text { entre si }(P>0,05) \text {. } \\
\text { a,b - médias de Idades das Plantas seguidas de mesma letra minúscula não } \\
\text { diferem entre si }(P>0,05) \text {. }\end{array}$} \\
\hline
\end{tabular}

As interações $G \times$ I foram não significativas, indicando que os efeitos de genótipos e idades das plantas são independentes. Em 
todas as leituras, os valores de IMB obtidos para Kadá foram significativamente superiores àqueles obtidos para Rotam-4. O efeito da idade da planta só pôde ser observado na leitura realizada aos 40 dias após a inoculação, quando os valores de IMB para plantas inoculadas 28 dias após a emergência revelaram-se significativamente inferiores aos valores obtidos para as demais idades testadas.

\subsection{ETAPA II: Reação de genótipos de tomateiro à inoculação com Clavibacter michiganensis subsp. michiganensis}

Foram detectadas diferenças significativas $(P<0,01)$ entre os doze genótipos avaliados, conforme está demonstrado na tabela 6 .

A metodologia de inoculação permitiu a diferenciação de três categorias de reação de genótipos. Jumbo e Alambra não diferiram significativamente de Rotam-4, sendo, portanto, considerados resistentes ao cancro bacteriano. No outro extremo, Santa Clara não diferiu do controle suscetível (Kadá), tendo, inclusive, apresentado o maior valor de IMB dentre os genótipos testados. Carmen, Débora max, IPA-6, Júpiter e Fanny mostraram reação intermediária, diferindo significativamente tanto do controle suscetível quanto do controle resistente. Finalmente, Densus e Olimpo não diferiram dos cinco genótipos intermediários, mas também não foram significativamente diferentes dos dois genótipos suscetíveis. 
Tabela 6. Reação de genótipos de tomateiro ao cancro bacteriano inoculados através de aspersão de suspensão bacteriana $\left(10^{8} \mathrm{ufc} / \mathrm{mL}\right)$ na face inferior da folha. Piracicaba, 2003

\begin{tabular}{ll}
\hline Genótipo & IMB $^{1}$ \\
\hline Carmen & $2,67 \mathrm{~b}$ \\
Débora max & $2,73 \mathrm{~b}$ \\
IPA-6 & $2,73 \mathrm{~b}$ \\
Santa Clara & $3,51 \mathrm{a}$ \\
Alambra & $1,44 \mathrm{c}$ \\
Júpiter & $2,79 \mathrm{~b}$ \\
Olimpo & $3,11 \mathrm{ab}$ \\
Fanny & $2,61 \mathrm{~b}$ \\
Jumbo & $1,51 \mathrm{c}$ \\
Densus & $2,91 \mathrm{ab}$ \\
Kadá* & $3,45 \mathrm{a}$ \\
Rotam-4** & $1,28 \mathrm{c}$ \\
Coeficiente de variação $=$ & $8,12 \%$
\end{tabular}

${ }^{1}$ Índice de Murcha Bacteriana, avaliado aos 30 dias após a inoculação

* - Controle suscetível

** - Controle resistente

a,b,c - médias seguidas de mesma letra não diferem pelo teste de Tukey (5\%). 


\subsection{ETAPA III: Controle do cancro bacteriano do tomateiro através do emprego de produtos químicos}

\subsubsection{Efeito do acibenzolar-S-metil e outros produtos fitossanitários no controle do cancro bacteriano em condições de telado}

A interação produtos $(P) \times$ esquemas de aplicação $(E)$ foi significativa $(P<0,05)$, indicando haver uma dependência dos efeitos desses dois fatores sobre o IMB. O resultado do desdobramento dessa interação está expresso na Tabela 7.

Tabela 7. Efeito de produtos fitossanitários, isolados ou em mistura, e de esquemas de aplicação dos produtos sobre o Índice de Murcha Bacteriana (IMB), avaliado aos 30 dias após a inoculação com Clavibacter michiganensis subsp. michiganensis. Piracicaba, 2003

\begin{tabular}{cccccc}
\hline $\begin{array}{c}\text { Esquemas de } \\
\text { Aplicação }\end{array}$ & ASM $^{2}$ & $\begin{array}{c}\text { ASM } \\
+ \\
\text { Mancozeb }\end{array}$ & $\begin{array}{c}\text { ASM } \\
+ \\
\text { Cobre }\end{array}$ & $\begin{array}{c}\text { Mancozeb } \\
+ \\
\text { Cobre }\end{array}$ & Oxitetraciclina \\
\hline $\mathrm{E}_{1}$ & $1,44 \mathrm{c} \mathrm{A}$ & $1,44 \mathrm{c} \mathrm{A}$ & $1,56 \mathrm{c} \mathrm{B}$ & $1,95 \mathrm{~b} \mathrm{~A}$ & 2,67 a A \\
$\mathrm{E}_{2}$ & $1,29 \mathrm{c} \mathrm{A}$ & $1,34 \mathrm{c} \mathrm{A}$ & $1,90 \mathrm{~b} \mathrm{~A}$ & $1,95 \mathrm{~b} \mathrm{~A}$ & 2,79 a A \\
$\mathrm{E}_{3}$ & $1,56 \mathrm{~cd} \mathrm{~A}$ & $1,44 \mathrm{~d} \mathrm{~A}$ & $1,78 \mathrm{c} \mathrm{AB}$ & $2,11 \mathrm{~b} \mathrm{~A}$ & 2,61 a A \\
Testemunha & & & $3,51^{*}$ & & \\
\hline
\end{tabular}

${ }^{1} \mathrm{E}_{1}=4$ aplicações dos produtos: aos 6 e 3 dias antes da inoculação e aos 3 e 6 dias após a inoculação

$\mathrm{E}_{2}=2$ aplicações dos produtos: aos 6 e 3 dias antes da inoculação

$\mathrm{E}_{3}=2$ aplicações dos produtos: aos 3 e 6 dias após a inoculação

${ }^{2}$ Acibenzolar-S-metil

${ }^{3}$ oxicloreto de cobre

a,b - em cada linha, médias seguidas de mesma letra minúscula, não diferem pelo teste de Tukey (5\%)

$A, B$ - em cada coluna, médias seguidas de mesma letra maiúscula, não diferem pelo teste de Tukey ( $5 \%)$

* - a Testemunha difere de cada uma das médias de tratamentos, pelo teste de Dunnett (5\%) 
Todas as combinações produto-esquema de aplicação resultaram em índices de murcha bacteriana médios que diferiram significativamente daquele obtido para a testemunha inoculada e não tratada (Dunnett, 5\%).

Quando foram realizadas quatro aplicações dos produtos (esquema 1), os tratamentos que apresentavam o ASM, isoladamente ou em mistura, foram os que proporcionaram maior redução na severidade da doença, não diferindo significativamente entre si. A oxitetraciclina e a mistura mancozeb + oxicloreto de cobre também resultaram em algum controle da doença, porém com menor eficiência que os tratamentos anteriormente citados.

No esquema 2, onde as aplicações dos produtos foram realizadas de maneira preventiva, isto é, antes da inoculação das plantas, novamente o ASM isolado e em mistura com mancozeb foram mais eficientes em controlar a doença, enquanto a oxitetraciclina promoveu a menor redução nos valores de IMB. Os tratamentos que incluíam oxicloreto de cobre tiveram eficiência intermediária aos demais.

Para o esquema com duas aplicações pós-inoculação (esquema 3), a mistura ASM + mancozeb resultou em menor valor de IMB, porém não diferiu significativamente do ASM aplicado isoladamente. Os tratamentos com a combinação de fungicidas e com oxitetraciclina foram aqueles menos eficientes no controle a doença, com os maiores valores de IMB tendo sido obtido para o antibiótico.

Comparando-se os esquemas de aplicação dentro de cada produto ou combinação de produtos, apenas para a mistura ASM + oxicloreto de cobre houve diferença significativa entre os esquemas, sendo que, para este tratamento, o esquema com quatro aplicações 
(E1) proporcionou maior redução no valor de IMB e o esquema com aplicações preventivas (E2), menor redução da doença. O esquema com aplicações pós-inoculação (E3) não diferiu dos outros dois esquemas.

\subsubsection{Efeito in vitro do acibenzolar-S-metil e outros produtos fitossanitários sobre Clavibacter michiganensis subsp. michiganensis}

O crescimento bacteriano só foi verificado para o tratamento testemunha, não suplementado com químicos, e sobre o meio NA suplementado com ASM isoladamente, nas duas concentrações testadas. $O$ isolado mostrou-se sensível à oxitetraciclina e às demais combinações de produtos, não tendo sido observado desenvolvimento de colônia bacteriana sobre os meios com tais agentes químicos. 


\section{DISCUSSÃO}

\subsection{ETAPA I: Metodologia de inoculação de Clavibacter michiganensis subsp. michiganensis em tomateiro}

O método de inoculação constitui um dos principais fatores a serem considerados quando se objetiva determinar o grau de resistência ou suscetibilidade de uma cultura a um patógeno. A importância da escolha de uma metodologia adequada é ainda maior quando envolve resistência do tipo horizontal ou quantitativa, como é o caso do cancro bacteriano do tomateiro, onde se verifica grande influência do ambiente, de aspectos relacionados à própria planta (por exemplo, seu estado nutricional) e ao patógeno (variabilidade de agressividade), e dos procedimentos adotados para a inoculação (técnica de inoculação e concentração de inóculo).

A data de avaliação mostrou-se tão importante para estudos de resistência ao cancro bacteriano quanto a própria técnica de inoculação e concentração de inóculo empregadas. As leituras realizadas aos 21 e 35 dias após a inoculação resultaram em valores de IMB que não permitiram a diferenciação estatística dos materiais em pelo menos um dos experimentos. A avaliação realizada aos 30 dias após a inoculação mostrou resultados mais consistentes e que melhor evidenciaram as diferenças entre os fatores de interesse. 
Na literatura, há grande diversidade de métodos descritos para a inoculação de $\mathrm{Cmm}$, incluindo tanto a inoculação da parte aérea quanto do sistema radicular. Essa variação entre os procedimentos de inoculação tem sido apontada como um dos fatores que dificultam a comparação entre os diferentes estudos de resistência de genótipos ao cancro bacteriano (Strider, 1969; Thyr, 1972; De Jong \& Honma, 1976; Berry et al., 1989; Gleason et al., 1993).

Os quatro métodos de inoculação empregados neste ensaio propiciaram infecção sistêmica das plantas de tomate, em todas as concentrações de inóculo adotadas (exceto testemunha), tanto para o genótipo suscetível quanto para o resistente.

A inoculação por aspersão de suspensão bacteriana na parte aérea da planta foi o método que se destacou por promover os maiores índices de doença. Segundo Henz et al. (1988), que avaliaram métodos de inoculação de Xanthomonas campestris pv. campestris para detecção de fontes de resistência em brássicas, a inoculação por aspersão reflete melhor as condições naturais de ocorrência de doenças, principalmente quando ocorre temperatura e umidade relativa altas. Sob condições de alta umidade, as bactérias penetram pelos hidatódios, nas margens foliares, e pelos estômatos, podendo colonizar o sistema vascular da planta. A pulverização de inóculo nas folhas de plântulas jovens de tomate levou à infecção através das câmaras subestomatais e tecidos vasculares (Gleason et al., 1991), mas, em experimentos anteriores, a aplicação foliar de inóculo não resultou em desenvolvimento da doença (Ark, 1944; Grogan \& Kendrick Junior, 1953). 
Diversos autores salientaram a importância da ocorrência de ferimentos para a entrada da bactéria na planta (Blood, 1931; Ark, 1944; Pine et al., 1955; Orth citado por Thyr, 1968), porém, os maiores índices de murcha bacteriana, em ambos os experimentos, da presente pesquisa foram observados em plantas cujas folhas, intactas, foram inoculadas através da pulverização de suspensão bacteriana. Strider \& Konsler (1965) obtiveram infecções de cotilédones sem ferimentos adotando o mesmo procedimento de inoculação. Entretanto, estes autores observaram a manifestação de lesões locais, não relatando a ocorrência de murcha dos cotilédones, enquanto, na presente pesquisa, verificou-se a ocorrência da infecção sistêmica e conseqüente murcha das folhas. Carlton et al. (1998) forneceram a primeira evidência de que $\mathrm{Cmm}$ pode penetrar nos folíolos de tomateiros através de hidatódios, afirmando que, embora a ocorrência de ferimentos anteriormente à pulverização do inóculo aumente a severidade da doença, está bem estabelecido que estes não são necessários para que haja infecção foliar.

De Jong \& Honma (1976) sugeriram a inoculação da haste das plantas para estudos genéticos, considerando-a menos sujeita à variação ambiental. No entanto, a técnica de inoculação da haste adotada no presente estudo, através da introdução de alfinete transpassando uma gota da suspensão de inóculo, na axila foliar, resultou nos mais baixos índices de doença e não permitiu diferenciação de resposta entre os genótipos resistente e suscetível. Segundo Hibberd et al. (1992), à mesma concentração de inóculo $\left(10^{5} \mathrm{ufc} / \mathrm{mL}\right)$, a doença evoluiu mais rapidamente em folíolos que nas hastes, indicando que as folhas são mais sensíveis a $\mathrm{Cmm}$ que os tecidos das hastes. Esses autores sugeriram que os dois tipos de 
tecido deveriam ser inoculados para a avaliação de resistência e que baixas incidência e severidade de cancro bacteriano em folhas devem ser reflexo do genótipo, constituindo um importante critério de seleção.

A inoculação do sistema radicular foi uma técnica intermediária às de aspersão de suspensão bacteriana e ferimento na haste em promover a doença nas plantas. Segundo Strider (1970) a inoculação de raízes falhou em promover a infecção de grande número de plantas, mesmo em altos níveis de inóculo, acarretando em resultados inconsistentes. Além dessa provável inconsistência de resultados, a inoculação de raiz tem a desvantagem de ser um método trabalhoso em comparação aos outros relatados.

A concentração de inóculo é tão importante quanto o método de inoculação, devendo ser ajustada a este, em estudos de resistência de materiais. Segundo Chang et al. (1992a), a concentração de inóculo influenciou o período de incubação e a severidade da doença, sendo que o aumento da concentração proporcionou redução no período de incubação e aumento da severidade.

Todas as concentrações adotadas nesse experimento proporcionaram infecção das plantas inoculadas, confirmando os resultados observados por Basu (1966) e Forster \& Echandi (1973), que verificaram infecção com níveis de inóculo variando de $10^{5} \mathrm{ufc} / \mathrm{mL}$ a $10^{9} \mathrm{ucf} / \mathrm{mL}$. Por outro lado, Thyr (1968) relatou que, com apenas cinco células bacterianas, plântulas de tomate podiam ser infectadas com $\mathrm{Cmm}$. Esses autores utilizaram técnicas de inoculação distintas, evidenciando a necessidade de se estabelecer qual a concentração de inóculo mais adequada a cada método. 
Os resultados obtidos nos experimentos concordam com as observações de Chang et al. (1992a), pois o aumento da concentração de inóculo resultou em incremento da severidade da doença das plantas inoculadas. Há que se ressaltar que os resultados aqui obtidos para método de inoculação e concentração de inóculo não devem ser analisados isoladamente, uma vez que interações significativas indicaram dependência entre os efeitos desses fatores. Assim, para o método de ferimento na haste, a concentração de inóculo praticamente não teve influência sobre o IMB, possivelmente por se tratar de um método de inoculação mais drástico. Além disso, essa técnica de inoculação resultou em baixos índices de doença, não possibilitando a diferenciação entre os genótipos, o mesmo sendo observado para a concentração $10^{6} \mathrm{ufc} / \mathrm{mL}$. Por outro lado, para a inoculação por aspersão, que proporcionou os melhores resultados no presente trabalho, verificou-se a necessidade da utilização de concentração de inóculo alta, provavelmente a partir de $10^{8} \mathrm{ufc} / \mathrm{mL}$.

O efeito da idade das plantas só pôde ser observado na leitura realizada aos 40 dias após a inoculação, possivelmente devido às condições de temperatura, conforme será discutido posteriormente. Os resultados obtidos nesta leitura mostraram que, quando inoculadas aos 28 dias após a emergência, as plantas se mostraram mais resistentes ao cancro bacteriano. Esses resultados concordam com relatos anteriores (Kendrick Junior \& Walker, 1948; Strider, 1970; Forster \& Echandi, 1973; Chang et al., 1992a), onde se observou que o aumento da idade da planta inoculada ocasionou uma redução na severidade da doença, ou seja, a inoculação de plantas mais jovens resultou em manifestação de sintomas mais precoces e 
mais intensos que a inoculação de plantas mais velhas. Nessas pesquisas, os autores observaram que em plantas com duas a três semanas ocorreu maior intensidade de doença e que naquelas com 28 dias ou mais houve retardamento no aparecimento e desenvolvimento dos sintomas.

A temperatura é outro fator que interage com a resposta de genótipo ao cancro bacteriano, além do método de inoculação e da idade da planta. Blood (1931) constatou que a doença progrediu mais rapidamente quando a temperatura do ar e do solo estiveram próximas de $28^{\circ} \mathrm{C}$, resultados que foram posteriormente confirmados por aqueles obtidos por Forster \& Echandi (1973).

A presente pesquisa não foi conduzida sob condições controladas de temperatura. No entanto, para os experimentos 3 e 4, observou-se redução das temperaturas médias registradas, comparativamente àquelas obtidas para os experimentos 1 e 2 . Por esta razão, optou-se pela realização de uma segunda leitura, aos 40 dias após a inoculação, para averiguar possível efeito da idade da planta a ser inoculada sobre o índice da doença. Uma vez que a temperatura é reconhecidamente um fator de grande influência sobre o cancro bacteriano do tomateiro e condições ambientais distintas foram observadas entre os dois ensaios dessa pesquisa, seria interessante averiguar a existência de uma interação entre metodologia de inoculação $x$ reação de genótipo $x$ temperatura, para que se possa indicar o procedimento adequado para cada condição ambiental. 


\subsection{ETAPA II: Reação de genótipos de tomateiro à inoculação com Clavibacter michiganensis subsp. michiganensis}

O uso de variedades resistentes é, sem dúvida, um dos mais efetivos meios de controle de doenças de plantas. Além de diminuir as perdas provocadas pela doença, o cultivo de materiais resistentes também reduz os custos decorrentes de pulverizações e os riscos de contaminação ambiental com substâncias químicas tóxicas (Agrios, 1997).

Os avanços para o desenvolvimento de materiais com resistência genética ao cancro bacteriano têm sido modestos. Genótipos selvagens de tomateiros, incluindo Lycopersicon pimpinellifolium, L. hirsutum e L. peruvianum, possuem resistência moderada à doença (Strider, 1969; Forster \& Echandi, 1973). Com relação a $L$. esculentum, alguns materiais apresentaram resistência caracterizada por menor multiplicação da bactéria nas hastes (De Jong \& Honma, 1976; Thyr, 1976; Boelema, 1980; van Steekelenburg, 1985; Honma \& Murakishi, 1986; Berry et al., 1989), redução na incidência (Boelema, 1980) e na severidade (Thyr, 1971b; van Steekelenburg, 1985; Berry et al., 1989).

Aparentemente, os materiais comerciais atualmente disponíveis no mercado não foram desenvolvidos visando resistência ao cancro, visto que não existem informações relacionadas a essa doença, diferentemente do que ocorre com outras doenças, como aquelas causadas por Fusarium oxysporum f. sp. Iycopersici, Verticillium albo-atrum v. dahliae, Stemphylium solani, Alternaria alternata f. sp. lycopersici, Pseudomonas syringae pv. tomato, Tomato 
mosaic virus (TOMV), Tomato yellow leaf curl virus (TYLCV) e nematóides (Meloidogyne incognita e M. javanica).

Diferentes graus de resistência foram observados no presente trabalho. O genótipo Santa Clara mostrou-se altamente suscetível ao cancro, discordando dos resultados anteriormente obtidos por Quezado-Soares \& Lopes (1994), que o classificaram como moderadamente resistente à doença. Assim, a utilização desse genótipo deve ser evitada, especialmente em regiões com condições favoráveis ao desenvolvimento da doença. Por outro lado, Jumbo confirmou a resistência ao cancro anteriormente observada por Carrijo (1991). Esse genótipo e Alambra mostraram-se promissores para o plantio em áreas com histórico de cancro bacteriano, caso confirmem, em condições de campo, o comportamento apresentado em telado.

\subsection{ETAPA III: Controle do cancro bacteriano do tomateiro através do emprego de produtos químicos}

A associação de substâncias químicas capazes de induzir a resistência de plantas a doenças e, consequentemente, proporcionar uma redução no emprego de produtos fitossanitários, de modo a diminuir custos de produção e aumentar a produtividade, tem sido um desafio aos pesquisadores. Produtos que constituem a base de programas padrões de pulverização de lavouras de tomate, os fungicidas protetores (cúpricos ou tiocarbamatos) e antibióticos têm proporcionado controle ineficiente das principais bacterioses que incidem na cultura. Neste contexto, o indutor de resistência acibenzolar-S-metil (ASM) tornou-se objeto de inúmeras pesquisas e 
vem sendo incluído em programas de manejo, isolado ou em mistura com outros produtos fitossanitários, visando controle mais efetivo de doenças.

As reduções significativas na severidade do cancro bacteriano proporcionadas pela aplicação de ASM, isolado ou em mistura, concordam com os resultados anteriormente obtidos para a mancha bacteriana e para a pinta bacteriana do tomateiro (Inbar et al., 1998; Fidantsef et al., 1999; Louws et al., 2001; Abbasi et al., 2002; Silva et al., 2003a,b), demonstrando a ação deste produto na proteção de plantas contra doenças bacterianas. Apesar de ter promovido a redução na severidade do cancro bacteriano, o ASM não apresentou efeito direto sobre $C$. michiganensis subsp. michiganensis, conforme demonstram os resultados do teste in vitro, evidenciando um modo de ação diferente dos demais produtos empregados no experimento, que agiram diretamente sobre a bactéria. Em ensaios in vitro, Kobayasti et al. (2001) não observaram toxidez direta do ASM sobre as bactérias Xanthomonas axonopodis pv. vesicatoria, Ralstonia solanacearum e Pseudomonas syringae pv. tomato. Silva, L. (2002) também não constatou ação direta do ASM sobre $X$. vesicatoria. Dessa maneira, o ASM preenche um dos critérios exigidos para ser considerado um indutor de resistência, que é o de não apresentar atividade antimicrobiana direta (Kessmann et al., 1994a,b; Sticher et al., 1997; Romero et al., 2001).

No presente experimento, quando aplicado isoladamente, o ASM foi tão eficiente quanto as suas misturas (ASM + mancozeb e ASM + oxicloreto de cobre) e superior aos produtos tradicionalmente empregados (fungicidas protetores e antibiótico) em promover redução do cancro bacteriano. Resultados semelhantes foram obtidos 
por Louws et al. (2001) e Silva et al. (2003a), em estudos de manejo da mancha bacteriana e da pinta bacteriana do tomateiro.

A mistura mancozeb + oxicloreto de cobre e o antibiótico oxitetraciclina promoveram algum controle da doença, porém em menor magnitude que aquele conferido pelos tratamentos contendo ASM. Embora a utilização destes produtos tenha resultado em significativa redução da severidade do cancro bacteriano, comparativamente à testemunha, diferentemente do que foi observado por Silva et al. (2003a) para a mancha bacteriana, está evidente a baixa eficiência dos mesmos. A resistência do isolado bacteriano a esses princípios ativos poderia ser apontada como uma das causas da baixa eficiência. No entanto, esta hipótese não se confirmou em ensaio in vitro, onde a bactéria mostrou-se sensível aos produtos. Segundo Romeiro (1995), fungicidas protetores (cúpricos e tiocarbamatos) e antibióticos são químicos pouco persistentes, não sistêmicos e de baixa absorção pelas plantas, refletindo em controle insatisfatório de doenças bacterianas.

O desempenho demonstrado pelo ASM em proteger as plantas de tomate contra o cancro bacteriano e doenças incitadas por outros patógenos (Benhamou \& Belanger, 1998; Inbar et al., 1998; Fidantsef et al., 1999; Anfoka, 2000; Louws et al., 2001; Castro et al., 2001; Silva et al., 2003a) o torna um componente importante e viável para o manejo integrado de doenças do tomateiro.

Para aplicar os resultados desse estudo no campo, pesquisas adicionais são necessárias para averiguar os fatores que possam afetar a resistência induzida pelo ASM. Esses fatores incluem: (a) genótipo - Louws et al. (2001), Romero et al. (2001) e Silva, L. (2002) verificaram variação na proteção contra a mancha bacteriana 
em função do genótipo avaliado; (b) modo de aplicação do indutor no presente estudo, o ASM foi aplicado via pulverização foliar, mas Anfoka (2000) e Silva et al. (2003b) observaram a viabilidade e eficiência da aplicação via solo; (c) número de aplicações - os resultados mostraram que duas aplicações antes da inoculação foram suficientes para conferir proteção às plantas. No entanto, Louws et al. (2001) afirmaram que o extenso período de proteção conferido pela resistência induzida em plantas monocotiledôneas não tem sido verificado para dicotiledôneas, o que pode implicar na necessidade de um maior número de aplicações. Friedrich et al. (1996) e Silva et al. (2003b) observaram a necessidade de reativação dos mecanismos de defesa, através de novas aplicações do indutor, para tabaco e tomate, respectivamente; (d) época de aplicação - apesar de não ter sido observada diferença significativa entre os esquemas testados nesse estudo (exceto para ASM + Cobre), as aplicações pré-infecção são mais apropriadas, uma vez que a resistência sistêmica adquirida (RSA) é um mecanismo de defesa induzível. Segundo Cole (1999), RSA é mais efetiva em restringir doenças quando ativada antes da entrada do patógeno; (e) aplicação do indutor de forma isolada ou combinado com outros produtos - quando aplicado isoladamente, o ASM resultou em menor severidade de doença, mesmo quando não diferiu significativamente das misturas com fungicidas. Essa eficiência, se confirmada no campo, pode representar uma redução de custos com produtos, além de diminuir os riscos de seleção de isolados bacterianos resistentes. Além desses fatores, há que se considerar possíveis efeitos do estádio de desenvolvimento e estado fisiológico das plantas e de condições ambientais, particularmente aquelas que provocam algum tipo de estresse na planta. 
Assim, a otimização dos fatores anteriormente citados, em condições de campo, certamente resultará numa medida de controle confiável e efetiva não somente ao cancro bacteriano como a outras doenças que incidem na cultura. 


\section{CONCLUSÕES}

Os resultados obtidos neste estudo permitem concluir que:

a) A inoculação através da aspersão de suspensão bacteriana, na concentração $10^{8} \mathrm{ufc} / \mathrm{mL}$, quatorze dias após a emergência das plantas, e avaliação aos 30 dias após a inoculação, foi a metodologia mais apropriada à avaliação de reação de genótipos de tomateiro ao cancro bacteriano.

b) Plantas inoculadas aos 28 dias após a emergência se mostraram mais resistentes ao cancro bacteriano.

c) Alambra e Jumbo foram os genótipos que mostraram maior resistência ao cancro bacteriano, sendo materiais promissores para o plantio em áreas com histórico da doença.

d) O indutor de resistência acibenzolar-S-metil, isolado ou em mistura com fungicida protetor, proporcionou os melhores resultados para proteção de plantas ao cancro bacteriano do tomateiro, quando comparado com fungicidas e antibiótico. 
e) O acibenzolar-S-metil, incorporado ao meio de cultura não inibiu o desenvolvimento da bactéria causadora do cancro bacteriano do tomateiro. 


\section{REFERÊNCIAS BIBLIOGRÁFICAS}

ABBASI, P.A.; SOLTANI, N.; CUPPELS, D.A.; LAZAROVITS, G. Reduction of bacterial spot disease severity on tomato and pepper plants with foliar applications of ammonium lignosulfonate and potassium phosphate. Plant Disease, v.86, n.11, p.1232-1236, 2002.

AGRAWAL, A.A.; TUZUN, S.; BENT, E. Induced plant defenses against pathogens, herbivous, biochemistry, ecology and agriculture. Saint Paul, Minnesota: APS Press, 1999. 390p.

AGRIOS, G.N. Plant Pathology. 4. ed. San Diego: Academic Press, 1997. 635p.

ANFOKA, G.H. Benzo-(1,2,3)-thiadiazole-7-carbothioic-acid-S-methyl ester induces systemic resistance in tomato (Lycopersicon esculentum Mill cv. Vollendung) to Cucumber mosaic virus. Crop Protection, v.19, n.6, p.401-405, 2000.

ARAÚJO, J.S.; OLIVEIRA, B.C.; GONÇALVES, K.S.; BARBOSA, P.A.S.N.; LUSQUINOS, H.S. Resistência a murcha bacteriana em tomateiro, induzida pelo acibenzolar-S-methil. Fitopatologia Brasileira, v.27, p.S54, 2002. Suplemento. 
ARK, P.A. Studies on bacterial cancker of tomato. Phytopathology, v.34, n.4, p.394-400, 1944.

AZEVEDO, L.A.S.; ARRUDA, J.A.A. Resposta de quatro cultivares de tomate a aplicação de acibenzolar-S-metil. Fitopatologia Brasileira, v.27, p.S54, 2002. Suplemento.

BASU, P.K. Conditions for symptomatological differentiation of bacterial canker, spot and speck on tomato seedlings. Canadian Journal of Plant Science, v.46, n.3, p.525-530, 1966.

BENHAMOU, N.; BELANGER, R. Benzothiadiazole-mediated induced resistance to Fusarium oxysporum f. sp. radicis-lycopersici in tomato. Plant Physiology, v.118, n.4, p.1203-1212, 1998.

BERRY, S.Z.; MADUMADU, G.G.; UDDIN, M.R.; COPLIN, D.L. Virulence studies and resistance to Clavibacter michiganensis ssp. michiganensis in tomato germoplasm. HortScience, v.24, n.2, p.362-365, 1989.

BLOOD, H.L. Bacterial canker of tomato. Utah Academy of Science Proceedings, v.8, p.55-58, 1931.

BOELEMA, B.H. Resistance to Corynebacterium michiganense in tomato cultivars and breeding lines. Phylophylactica, v.12, p.81$82,1980$. 
BRISSET, M.N.; CESBRON, S.; THOMPSON, S.V.; PAULIN J.P. Acibenzolar-S-methyl induces accumulation of defense-related enzymes in apple and protects from fire blight. European Journal of Plant Pathology, v.106, n.6, p.529-536, 2000.

BRYAN, M.K. Studies on bacterial canker of tomato. Journal of Agricultural Research, v.41, n.12, p.825-851, 1930.

CARLTON, W.M.; BRAUN, E.J.; GLEASON, M.L. Ingress of Clavibacter michiganensis subsp. michiganensis into tomato leaves through hydatodes. Phytopathology, v.88, n.6, p.525-529, 1998.

CARRIJO, I.V. "Jumbo AG-592": nova cultivar de tomate. Horticultura Brasileira, v.9, n.2, p.97, 1991.

CASTRO, R.M.; VIEIRA, M.; SCANAVACHI, V.; AZEVEDO, L.A.S. Efeito do ativador de plantas acibenzolar-S-methyl na proteção contra doenças, incremento da produção e qualidade de frutos em tomate estaqueado. Fitopatologia Brasileira, v.26, p.492-493, 2001. Suplemento.

CHANG, R.J.; RIES, S.M.; PATAKY, J.K. Dissemination of Clavibacter michiganensis subsp. michiganensis by practices used to produce tomato transplants. Phytopathology, v.81, n.10, p.1276-1281, 1991. 
CHANG, R.J.; RIES, S.M.; PATAKY, J.K. Effects of temperature, plant age, inoculum concentration, and cultivar on the period and severity of bacterial canker of tomato. Plant Disease, v.76, n.11, p.1150-1155, 1992a.

CHANG, R.J.; RIES, S.M.; PATAKY, J.K. Local sources of Clavibacter michiganensis subsp. michiganensis in the development of bacterial canker on tomatoes. Phytopathology, v.82, n.5, p.553-560, 1992b.

COLE, D.L. The efficacy of acibenzolar-S-methyl, an inducer of systemic acquired resistance, against bacterial and fungal diseases of tobacco. Crop Protection, v.18, n.4, p.267-273, 1999.

CSINOS, A.S.; PAPPU, H.R.; MCPHERSON, R.M.; STEPHENSON, M.G. Management of Tomato spotted wilt virus in flue-cured tobacco with acibenzolar-S-methyl and imidacloprid. Plant Disease, v.85, n.3, p.292-296, 2001.

DE JONG, J.; HONMA, S. Evaluation of screening techniques and determination of criteria for assessing resistance to Corynebacterium michiganense in tomato. Euphytica, v.25, n.2, p.405-414, 1976.

DELANEY, T.P. Genetic dissection of acquired resistance to disease. Plant Physiology, v.113, n.1, p.5-12, 1997. 
DENARDIN, N.D.; DALLA NORA, T.; WEBBER, T.; BARBOZA, J.C.; CARDOSO, E.P.; CASTRO, R.M. Efeito da aplicação de acibenzolarS-metil na proteção contra Erwinia carotovora subsp. carotovora em batateira. Fitopatologia Brasileira, v.27, p.S59, 2002. Suplemento.

EIKEMO, H.; STENSVAND, A.; TRONSMO, A.M. Induced resistance as a possible means to control diseases of strawberry caused by Phytophthora spp. Plant Disease, v.87, n.4, p.345-350, 2003.

FARLEY, J.D. Recovery of Corynebacterium michiganense from overwintered tomato stems by the excised petiole inoculation method. Plant Disease Reporter, v.55, n.7, p.654-656, 1971.

FIDANTSEF, A.L.; STOUT, M.J.; THALER, J.S.; DUFFEY, S.S.; BOSTOCK, R.M. Signal interactions in pathogen and insect attack: expression of lipoxygenase, proteinase inhibitor II, and pathogenesis-related P4 in the tomato Lycopersicon esculentum. Physiological and Molecular Plant Pathology, v.54, p.97-114, 1999.

FNP CONSULTORIA \& COMÉRCIO. AGRIANUAL 2004: anuário da agricultura brasileira. São Paulo, 2003. p.476.

FORSTER, R.L.; ECHANDI, E. Relation of age of plants, temperature, and inoculum concentration of bacterial canker development in resistant and susceptible Lycopersicon spp. Phytopathology, v.63, n.6, p.773-777, 1973. 
FRIEDRICH, L.; LAWTON, K.; RUESS, W.; MASNER, P.; SPECKER, N.; GUT-RELLA, M.; MEIER, B.; DINCHER, S.; STAUB, T.; UKNES, S.; METRAUX, J.P.; KESSMAN, H.; RYALS, J. A benzothiadiazole derivative induces systemic acquired resistance in tobacco. Plant Journal, v.10, p.61-70, 1996.

GALLI, F; TOKESHI, H. Doenças do tomateiro. In: MINAMI, K., HAAG, H.P. O tomateiro. Campinas: Fundação Cargill, 1979. p.240-294.

GITAITIS, R.D. Bacterial canker. In: JONES, J.B.; JONES, J.P.; STALL, R.E.; ZITTER, T.A. (Ed.) Compendium of tomato diseases. St. Paul: APS Press, 1991. p.25-26.

GITAITIS, R.D.; BEAVER, R.W.; VOLOUDAKIS, A.E. Detection of Clavibacter michiganensis subsp. michiganensis in symptomless tomato transplants. Plant Disease, v.75, n.8, p.834-838, 1991.

GLEASON, M.L.; GITAITIS, R.D.; RICKER, M.D. Recent progress in understanding and controlling bacterial canker of tomato in Easthern North America. Plant Disease, v.77, n.11, p.1069-1076, 1993.

GLEASON, M.L.; BRAUN, E.J.; CARLTON, W.M.; PETERSON, R.H. Survival and dissemination of Clavibacter michiganensis subsp. michiganensis in tomatoes. Phytopathology, v.81, n.12, p.15191523, 1991. 
GOTO, M. Fundamentals of bacterial plant pathology. San Diego: Academic Press, 1992. 342p.

GROGAN, R.G.; KENDRICK JUNIOR, J.B. Seed transmission, mode of overwintering and spread of bacterial canker of tomato caused by Corynebacterium michiganense. Phytopathology, v.43, n.9, p.473, 1953.

HASSAN, A.A.; STRIDER, D.L.; KONSLER, T.R. Application of cotiledonary symptons in screening for resistance to tomato bacterial canker and in host range studies. Phytopathology, v.58, n.2, p.233-239, 1968.

HENZ, G.P.; TAKATSU, A.; REIFSCHNEIDER, F.J.B. Avaliação de métodos de inoculação de Xanthomonas campestris patovar campestris para detecção de fontes de resistência em brássicas. Fitopatologia Brasileira, v.13, n.3, p.207-210, 1988.

HIBBERD, A.M.; HEATON, J.B.; FINLAY, G.P.; DULLAHIDE, S.R. A greenhouse method for selecting tomato seedlings resistant to bacterial canker. Plant Disease, v.76, n.10, p.1004-1007, 1992.

HONMA, S.; MURAKISHI, H.H. MI-2000, MI-100 and MI-08 tomato breeding populations. HortScience, v.21, p.1244-1245, 1986. 
INBAR, M.; DOOSTAR, H.; SONODA, R.M.; LEIBEE, G.L.; MAYER, T. Elicitors of plant defensive system reduce insect densities and disease incidence. Journal of Chemical Ecology, v.24, n.1, p.135-149, 1998.

JARVIS, W.R. Bacterial canker of tomatoes. Annual Report Glasshouse of Crops Research Institute, p.172-177, 1981.

JENSEN, B.D.; LATUNDE DADA, A.O.; HUDSON, D.; LUCAS, J.A. Protection of Brassica seedlings against downy mildew and damping-off by seed treatment with CGA 245704, an activator of systemic acquired resistance. Pesticide Science, v.52, n.1, p.6369, 1998.

JESUS JUNIOR, W.C.; ROMEIRO, R.S.; RODRIGUES, F.A.; PEREIRA, J.L.A. Um derivado do benzotiadiazólico como ativador químico de mecanismos de defesa em feijoeiro contra patógenos. Fitopatologia Brasileira, v.24, p.293, 1999. Suplemento.

KENDRICK JUNIOR, J.B.; WALKER, J.C. Predisposition of tomato to bacterial canker. Journal of Agricultural Research, v.77, p.169186, 1948.

KESSMANN, H.; STAUB, T.; LIGON,J.; OOSTENDORP, M.; RYALS, J. Activation of systemic acquired resistance in plants. European Journal of Plant Pathology, v.100, n.6, p.359-369, 1994a. 
KESSMANN, H.; STAUB, T.; HOFMANN, C.; MAETZKE, T.; HERZOG, J.; WARD, E.; UKNESS, S.; RYALS, J. Induction of systemic acquired disease resistance in plants by chemicals. Annual Review of Phytopathology, v.32, p.439-459, 1994b.

KIMURA, O.; ALMEIDA, O.C.; AKIBA, F. Cultivares nacionais de tomateiro (Lycopersicon esculentum Mill.) resistentes ao cancro bacteriano. In: CONGRESSO DA SOCIEDADE DE OLERICULTURA DO BRASIL, 17., Juazeiro, BA, 1977. Resumos. Brasília: EMBRAPA, 1977. p.190.

KIMURA, O.; ALMEIDA, O.C.; ROBBS, C.F.; AKIBA, F. Estudo comparativo de alguns métodos de inoculação para o "cancro bacteriano" do tomateiro. Fitopatologia Brasileira, v.3, n.1, p.8990, 1978.

KNIGHT, S.C.; ANTHONY, V.M.; BRADY, A.M.; GREELAND, A.J.; HEANEY, S.P.; MURRAY, D.C.; POWELL, K.A.; SCHULZ, M.A.; SPINKS, C.A.; WORTHINGTON, P.A.; YOULE, D. Rationale and perspectives of the development of fungicides. Annual Review of Phytopathology, v.35, p.349-372, 1997.

KOBAYASTI, L.; SILVA, L.H.C.P.; CAMPOS, J.R., SOUZA, R.M.; RESENDE, M.L.V; CASTRO, R.M. Efeito "in vitro" do indutor de resistência acibenzolar-S-metil sobre bactérias patogênicas ao tomateiro. Fitopatologia Brasileira, v.26, p.293-294, 2001. Suplemento. 
KUROZAWA, C. Cancro bacteriano do tomateiro. O Biológico, v.50, p.105-113, 1984.

KUROZAWA, C.; LEITE JUNIOR, R.P. Comparação de dois métodos de avaliação de cancro bacteriano (Corynebacterium michiganense) (Smith) Jensen do tomateiro. Summa Phytopathologica, v.7, n.1/2, p.9, 1981a.

KUROZAWA, C.; LEITE JUNIOR, R.P. Comportamento de seis cultivares de tomateiro sob seis métodos de inoculação de Corynebacterium michiganense (Smith) Jensen. Summa Phytopathologica, v.7, n.1/2, p.15-16, 1981b.

KUROZAWA, C.; PAVAN, M.A. Doenças do tomateiro (Lycopersicon esculentum Mill.) In: KIMATI, H.; AMORIM, L.; BERGAMIM FILHO, A.; CAMARgO, L.E.A.; ReZEndE, J.A.M. (Ed.). Manual de Fitopatologia - doenças das plantas cultivadas. 3. ed. São Paulo: Agronômica Ceres, 1997. v.2. p.690-719.

LOPES, C.A. Doenças bacterianas da batata. Informe Agropecuário, v.7, p.40-42, 1981.

LOPES, C.A. Bacterioses de hortaliças: situação atual e perspectivas de controle. In: ZAMBOLIN, L. (Ed.). Manejo de doenças, pragas e plantas daninhas. Viçosa: UFV, Imprensa Universitária, 2000. p.187-208. 
LOPES, C.A.; SANTOS, J.R.M. Doenças do tomateiro. Brasília: EMBRAPA-SPI, 1994. 67p.

LOUWS, F.J.; WILSON, M.; CAMPBELL, H.L.; CUPPELS, D.A.; JONES, J.B.; SHOEMAKER, P.B.; SAHIN, F.; MILLER, S.A. Field control of bacterial spot and bacterial speck of tomato using a plant activator. Plant Disease, v.85, n.5, p.481-488, 2001.

MAFFIA, L.A.; MARTINS, M.C.P.; MATSUOKA, K. Doenças do tomateiro. Informe Agropecuário, v.6, n.66, p.42-60, 1980.

MEDINA-MORA, C.M.; HAUSBECK, M.K.; FULBRIGHT, D.W. Bird's eye lesions of tomato fruit produced by aerosol and direct application of Clavibacter michiganensis ssp. michiganensis. Plant Disease, v.85, n.1, p.88-91, 2001.

MIGUEL-WRUCK, D.S.; OLIVEIRA, J.R.; ROMEIRO, R.S.; DHINGRA, O.D. Sobrevivência e transmissão de Clavibacter michiganensis subsp. michiganensis em estacas de bambu infestadas artificialmente para plantas de tomate. Summa Phytopathologyca, v.27, n.3, p. 283-287, 2001.

MINAMI, K.; HAAG, H.P. O tomateiro. 2. ed. Campinas: Fundação Cargill, 1989. 397p.

MISAGHI, I.J. Physiology and biochemistry of plant-pathogen interaction: induced resistance. Tucson: University of Arizon, 1982. 238p. 
MORGADO, H.S.; LOPES, C.A.; TAKATSU, A. Virulência de isolados de Pseudomonas solanacearum à berinjela. Fitopatologia Brasileira, v.17, n.4, p.430-434, 1992.

NEDUMARAN, S.; VIDHYASEKARAN, P. Seed-borne infection of Corynebacterium michiganense in tomato. Indian Phytopathology, v.35, n.4, p.510-511, 1982.

NIELSEN, L.W.; HAYNES JUNIOR, F.L. Resistance in Solanum tuberosum to Pseudomonas solanacearum. American Potato Journal, v.37, n.8, p.260-267, 1960.

PARADELA, A.; SCACHETTI, A.P.; MUNHOZ, R.; BORIM JUNIOR, N.; CALAFIORI, M.H. Eficiência de Bion (acibenzolar-S-methyl) como indutor de resistência para o complexo bacteriano (Xanthomonas vesicatoria, Pseudomonas syringae pv. tomato e Clavibacter michiganensis subsp. michiganensis) e insetos vetores de fitoviroses na cultura do tomate (Lycopersicon esculentum L.). Fitopatologia Brasileira, v.27, p.S67-68, 2002. Suplemento.

PASCHOLATTI, S.F.; STANGARLIN, J.R.; RESENDE, M.L.V.; ROMEIRO, R.S.; CASTRO, R.M.; STADINIK, M.; LEITE, B. Bioquímica fitopatológica e indução de resistência. Fitopatologia Brasileira, v.24, p.241, 1999. Suplemento. 
PINE, T.S.; GROGAN, R.G.; HEWITT, W.B. Pathological anatomy of bacterial canker of young tomato plants. Phytopathology, v.45, p.267-271, 1955.

QUEZADO-SOARES, A.M.; LOPES, C.A. Reação de genótipos de tomateiro ao cancro bacteriano. Horticultura Brasileira, v.12, n.2, p.154-160, 1994.

RESENDE， M.L.V.; PEREZ， J.O.; LOPES, F.C.A.; MORAES, S.R.G.; FIORINI, C.V.A.; SILVA, I.L.S.S. Otimização de doses e épocas de aplicação do acibenzolar-S-metil (ASM) em mudas de cacau. Fitopatologia Brasileira, v.27, p.S228, 2002. Suplemento.

RIZZO, A.A.N.; FERREIRA, M.R.; BRAZ, L.T. Ação do acibenzolar-Smethyl (BTH) isolado e em combinação com fungicidas no controle do cancro da haste em melão rendilhado. Horticultura Brasileira, v.21, n.2, p.238-240, 2003.

ROMEIRO, R.S. Bactérias Fitopatogênicas. Viçosa: UFV, Imprensa Universitária, 1995. 283p.

ROMERO, A.M.; KOUSIK, C.S.; RITCHIE, D.F Resistance to bacterial spot in bell pepper induced by acibenzolar-S-methyl. Plant Disease, v.85, n.2, p.189-194, 2001.

RYALS, J.A.; UKNES, S.; WARD, F. Systemic acquired resistance. Plant Physiology, v.104, n.4, p.1109-1112, 1994. 
SHOEMAKER, P.B.; ECHANDI, E. Seed and plant bed treatments for bacterial canker of tomato. Plant Disease Reporter, v.60, n.2, p.163-166, 1976.

SILVA, L.H.C.P. Resistência sistêmica ativada pelo acibenzolar-S-metil contra doenças no tomateiro. Lavras, 2002. 89p. Dissertação (Mestrado) - Universidade Federal de Lavras.

SILVA, L.H.C.P.; CAMPOS, J.R.; KOBAYASTI, L.; SOUZA, R.M.; RESENDE, M.L.V.; CASTRO, R.M. Efeito do acibenzolar-S-metil (ASM) na proteção contra Ralstonia solanacearum em tomateiro. Fitopatologia Brasileira, v.26, p.294-295, 2001. Suplemento.

SILVA, L.H.C.P.; CAMPOS, J.R.; CAMPOS, V.P.; DUTRA, M.R. Efeito do acinbenzolar-S-metil (ASM) e da abamectina na proteção de cultivares de tomateiro contra Meloydogine sp. Fitopatologia Brasileira, v.27, p.S194-195, 2002a. Suplemento.

SILVA, L.H.C.P.; CAMPOS, J.R.; CAMPOS, V.P.; DUTRA, M.R. Época de aplicação do acinbenzolar-S-metil (ASM) e da abamectina no controle de Meloydogine sp. em tomateiro. Fitopatologia Brasileira, v.27, p.S194, 2002b. Suplemento.

SILVA, L.H.C.P.; RESENDE, M.L.V.; SOUZA, R.M.; CAMPOS, J.R.; Efeito do indutor de resistência acibenzolar-S-metil na proteção contra Xanthomonas vesicatoria, Oidium lycopersici e Septoria lycopersici em tomateiro. Summa Phytopathologyca, v.29, n.3, p. 244-248, 2003a. 
SILVA, L.H.C.P.; RESENDE, M.L.V.; SOUZA, R.M.; CAMPOS, J.R.; CASTRO, A.M.S. Indução de resistência contra Xanthomonas vesicatoria em tomateiro por acibenzolar-S-metil. Summa Phytopathologyca, v.29, n.2, p. 177-181, 2003b.

SILVA, R.A. Indução de resistência em cenoura através do acibenzolar-S-methyl visando reduzir a incidência de podridão mole de Erwinia carotovora durante a pós-colheita. Fitopatologia Brasileira, v.27, p.S69, 2002. Suplemento.

SOARES, R.M.; MARINGONI, A.C. Efeito do acibenzolar-S-methyl sobre a germinação e desempenho de sementes de feijoeiro e indução de resistência à murcha-de-Curtobacterium. Summa Phytopathologyca, v.28, n.1, p.41-45, 2002.

STICHER, L.; MAUCH-MANI, B.; METRAUX, J.P. Systemic acquired resistance. Annual Review of Phytopathology, v.35, p.235-270, 1997.

STRIDER, D.L. Survival studies with the tomato bacterial canker organism. Phytopathology, v.57, n.10, p.1067-1071, 1967.

STRIDER, D.L. Bacterial canker of tomato caused by Corynebacterium michiganense: a literature review and bibliography. North Carolina Agricultural Experiment Station, 1969, 110p. (Technical Bulletin, 193). 
STRIDER, D.L. Tomato seedling inoculations with Corynebacterium michiganense. Plant Disease Reporter, v.54, n.1, p.36-39, 1970.

STRIDER, D.L.; KONSLER, T.R. Cotiledonary symptoms of bacterial canker of tomato. Plant Disease Reporter, v.49, n.7, p.634-635, 1965.

THYR, B.D. Resistance to bacterial canker in tomato, and its evaluation. Phytopathology, v.58, n.3, p.279-281, 1968.

THYR, B.D. Corynebacterium michiganense isolated from naturally infected Solanum triflorum. Plant Disease Reporter, v.55, n.4, p.336-337, 1971a.

THYR, B.D. Resistance to Corynebacterium michiganense isolates on Lycopersicon accessions. Phytopathology, v.61, p.972-974, 1971b.

THYR, B.D. Virulence of Corynebacterium michiganense isolates on Lycopersicon accessions. Phytopathology, v.62, n.9, p.1082$1084,1972$.

THYR, B.D. Inheritance of resistance to Corynebacterium michiganense in tomato. Phytopathology, v.66, p.1116-1119, 1976. 
THYR, B.D.; SAMUEL, M.J.; BROWN, P.G. New solanaceous host records for Corynebacterium michiganense. Plant Disease Reporter, v.59, n.7, p.595-598, 1975.

TIGHELAAR, E.C. Botany and culture. In: JONES, J.B., JONES, J.P., STALL, R.E., ZITTER, T.A. (Ed.). Compendium of tomato diseases. St. Paul: APS Press, 1991. p.2-4.

TOKESHI, H.; CARVALHO, P.C.T. Doenças do tomateiro - Lycopersicon esculentum Mill. In: GALLI, F. (Ed.). Manual de Fitopatologia doenças das plantas cultivadas. 2. ed. São Paulo: Agronômica Ceres, 1980. v.2. p.511-552.

VAN STEEKELENBURG, N.A.M. Resistance to Corynebacterium michiganense in tomato genotypes. Euphytica, v.34, n.2, p.245250, 1985.

VOLCANI, Z.; ZUTRA, D.; COHN, R. A new leaf and fruit spot disease of pepper caused by Corynebacterium michiganense. Plant Disease Reporter, v.54, n.9, p.804-806, 1970.

WAKIMOTO, S.; UEMATSU, T.; MUKOO, H. Bacterial canker disease of tomato in Japan. I - Isolation and identification of the causal bacteria, and resistance of tomato against the disease. Bulletin National of Institute of Agricultural Science of Plant Pathology and Entomology, v.22, p.269-281, 1968. 